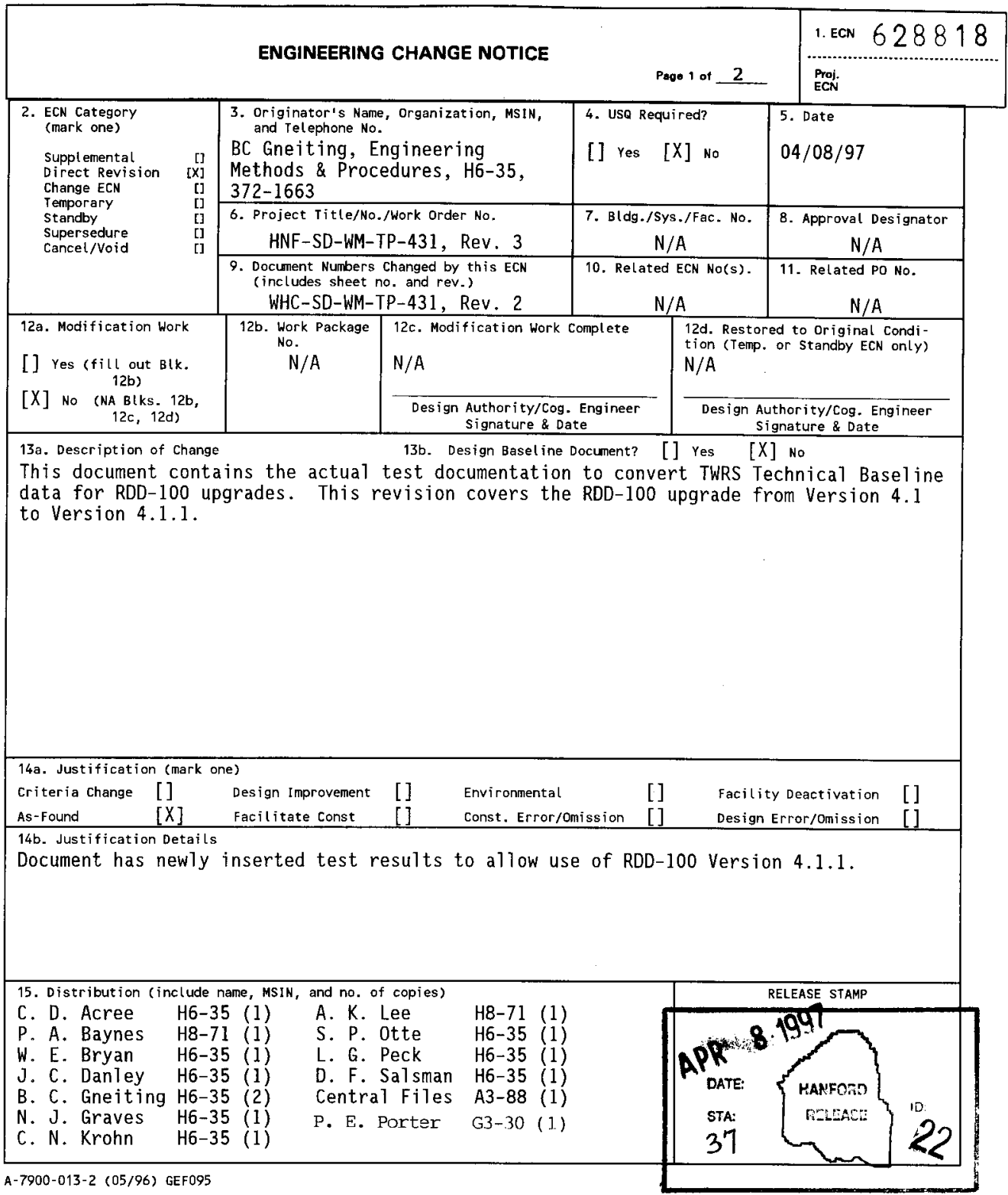




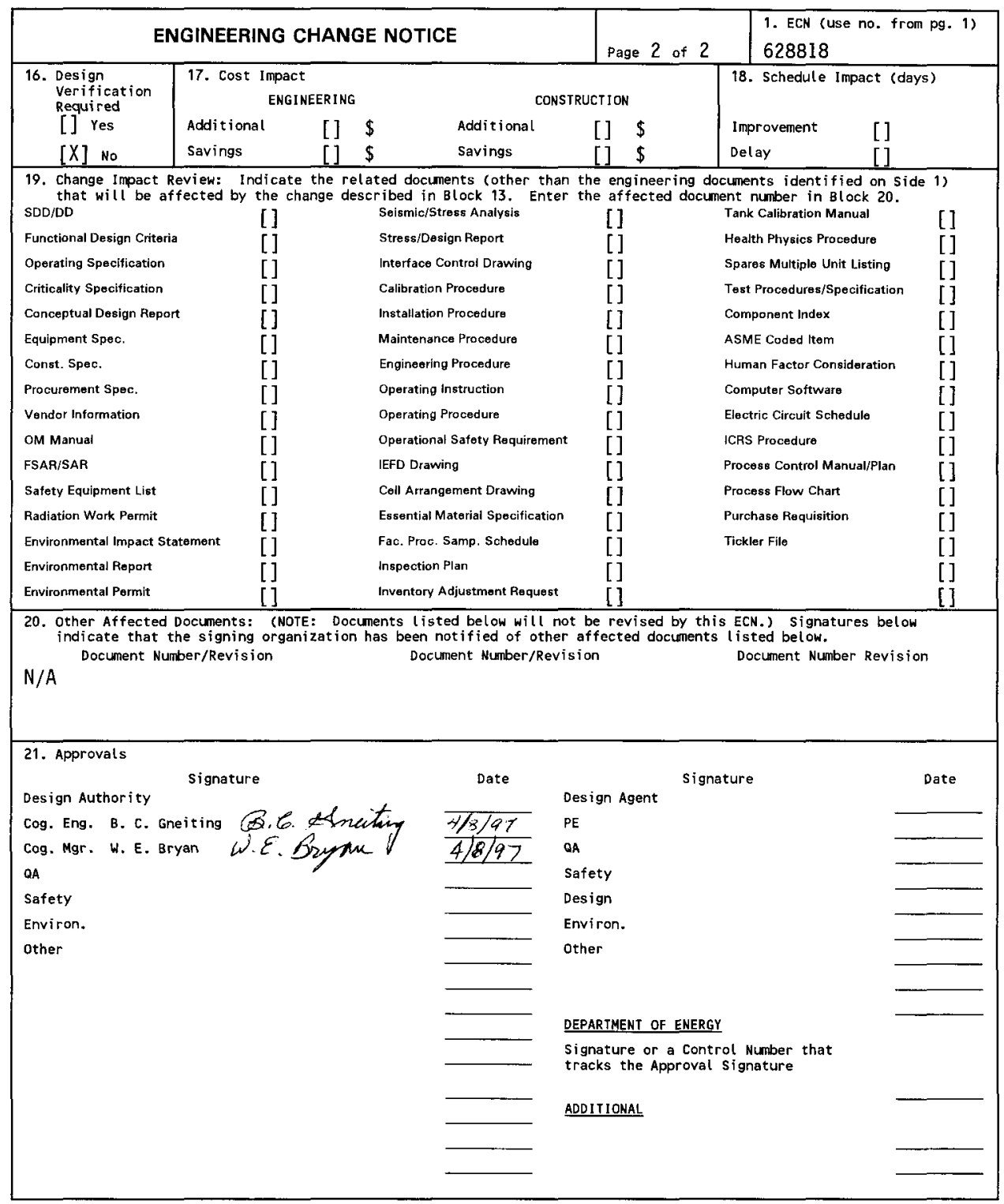




\title{
Test Documentation to Convert TWRS Baseline Data for RDD-100 Upgrades
}

\author{
B. C. Gneiting \\ J. C. Danley \\ Lockheed Martin Hanford Corp., Richland, WA 99352 \\ U.S. Department of Energy Contract DE-AC06-96RL13200 \\ EDT/ECN: $628818 \quad$ UC: 905 \\ Org Code: 74220 Charge Code: D1MD1 \\ B\&R Code: EW3120075 Total Pages: 55
}

Key Words: RDD-100, Test Pian, requirements management, database.

Abstract: This document describes the test documentation required for converting between different versions of the RDD-100 software application. The area of focus is the successful conversion of the master data set between different versions of the database tool and their corresponding data structures.

TRADEMARK DISCLAIMER. Reference herein to any specific comercial product, process, or service by trade name, trademark, manufacturer, or otherwise, does not necessarily constitute or imply its endorsement, recommendation, or favoring by the United States Government or any agency thereof or its contractors or subcontractors.

Printed in the United States of America. To obtain copies of this document, contact: Document Control Services, P.0. Box 950, Mailstop H6-08, Richland WA 99352, Phone (509) 372-2420;

Fax (509) 376-4989.

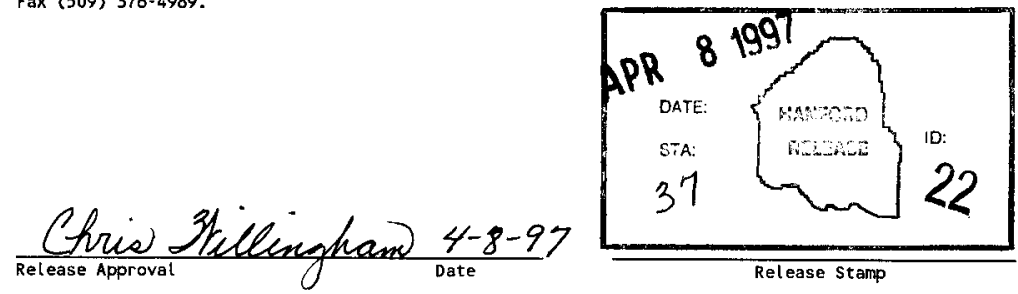

Approved for Public Release 
RECORD OF REVISION

(1) Document Number

HNF-SD-WM-TP-431

Page 1

Rev. 3

(2) Title

Test Documentation to Convert TWRS Baseline Data for RDD-100 Upgrades. CHANGE CONTROL RECORD

\begin{tabular}{|c|c|c|c|}
\hline \multirow{2}{*}{ Revision } & \multirow{2}{*}{ (4) Description of Change - Replace, Add, and Delete Pages } & \multicolumn{2}{|c|}{ Authorized for Release } \\
\hline & & (5) Cog. Engr. & (6) Cog. Mgr. \\
\hline 1 & $\begin{array}{l}\text { (7) Replace WHC-SD-WM-TP-431 Rev. } 0 \text { with } \\
\text { WHC-SD-WM-TP-431 Rev. } 1 \text { ECN-623906 }\end{array}$ & $\begin{array}{l}\text { BC Gneiting } \\
05 / 02 / 96\end{array}$ & $\begin{array}{l}\text { NG Awada11a } \\
05 / 02 / 96\end{array}$ \\
\hline 2 & $\begin{array}{l}\text { Rep } 1 \text { ace WHC-SD-WM-TP-431 Rev. } 1 \text { with WHC- } \\
\text { SD-WM-TP-431 Rev. } 2 \text { ECN-623907 }\end{array}$ & $\begin{array}{l}\text { BC Gneiting } \\
06 / 10 / 96\end{array}$ & $\begin{array}{l}\text { NG Awada11a } \\
06 / 10 / 96\end{array}$ \\
\hline${ }^{3} R S$ & $\begin{array}{l}\text { Replace WHC-SD-WM-TP-431 Rev. } 2 \text { with HNF- } \\
\text { SD-WM-TP-431 Rev. } 3 \text { ECN-628818 }\end{array}$ & 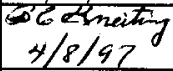 & $\begin{array}{l}\text { W.E. Bryan } \\
4 / 8197\end{array}$ \\
\hline & & & \\
\hline & & & \\
\hline & & & \\
\hline & & & \\
\hline & & & \\
\hline & & & \\
\hline & & & \\
\hline & & & \\
\hline & & & \\
\hline & & & \\
\hline & & & \\
\hline & & & \\
\hline & & & \\
\hline & & & \\
\hline & & & \\
\hline & & & \\
\hline & & & \\
\hline & & & \\
\hline & & & \\
\hline & & & \\
\hline & & & \\
\hline & & & \\
\hline & & & \\
\hline & & & \\
\hline & & & \\
\hline & & & \\
\hline & & & \\
\hline & & & \\
\hline & 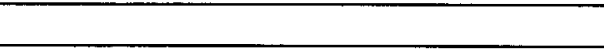 & & \\
\hline
\end{tabular}




\section{TEST DOCUMENTATION TO CONVERT TWRS BASELINE DATA FOR RDD-100 UPGRADES}

Brent C. Gneiting Jack C. Danley April 8, 1997 


\section{TABLE OF CONTENTS}

1.0 INTRODUCTION $\ldots \ldots \ldots \ldots \ldots \ldots \ldots \ldots \ldots \ldots \ldots \ldots \ldots \ldots \ldots \ldots \ldots \ldots \ldots \ldots$

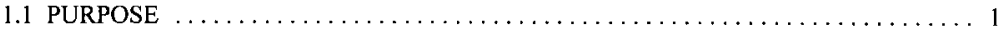

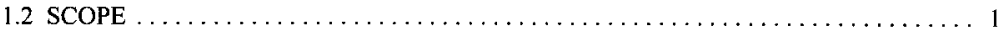

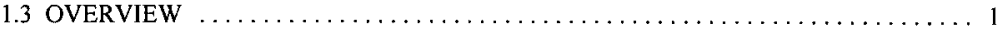

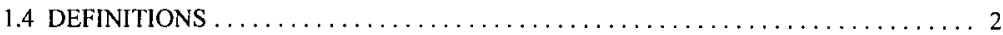

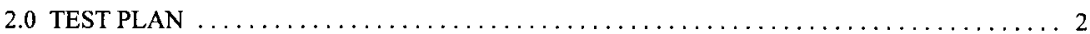

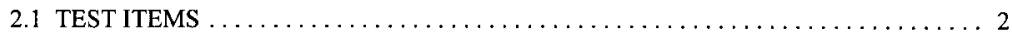

2.2 FEATURES TO BE TESTED/NOT TO BE TESTED $\ldots \ldots \ldots \ldots \ldots \ldots \ldots \ldots \ldots 2$

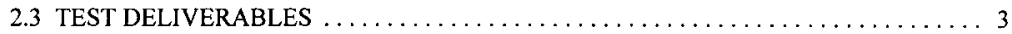

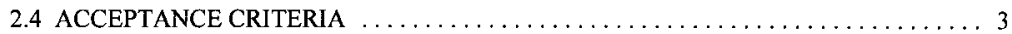

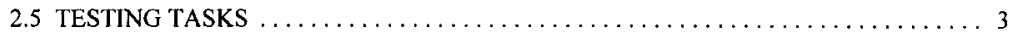

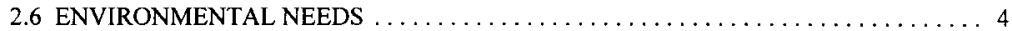

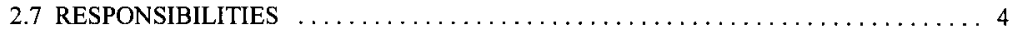

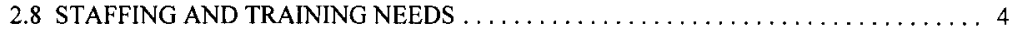

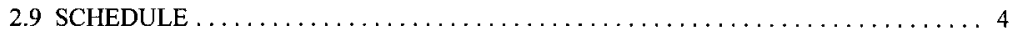

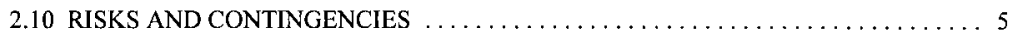

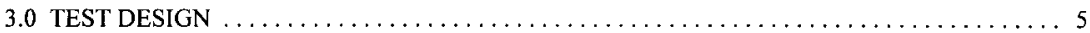

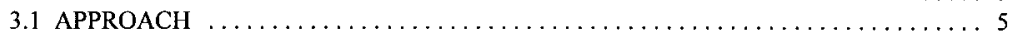

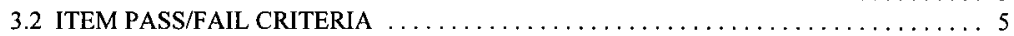

3.3 SUSPENSION CRITERIA AND RESUMPTION REQUIREMENTS $\ldots \ldots \ldots \ldots \ldots .5$

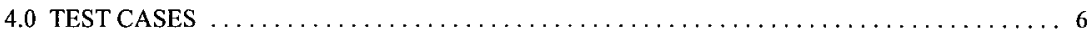

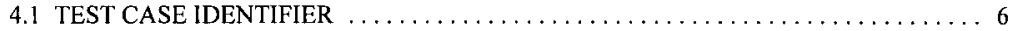

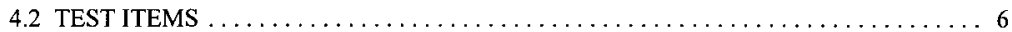

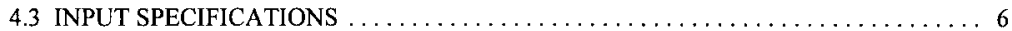

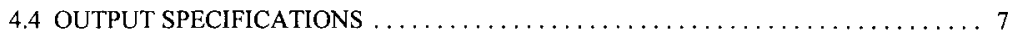

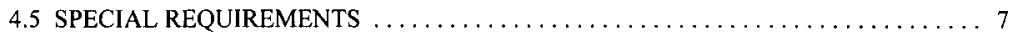

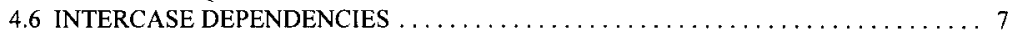

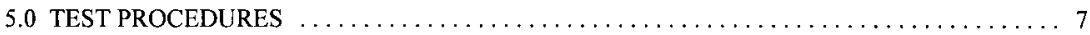

6.0 TEST ITEM TRANSMITTAL LIST $\ldots \ldots \ldots \ldots \ldots \ldots \ldots \ldots \ldots \ldots \ldots \ldots \ldots \ldots \ldots$

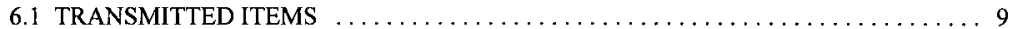

6.2 LOCATION . . . . . . . . . . . . . . . . . . . . . . . . . . . 9

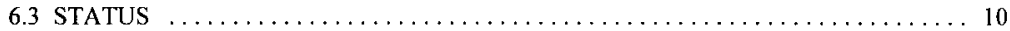

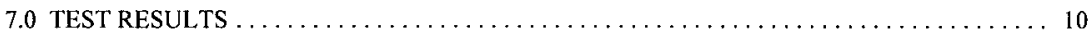

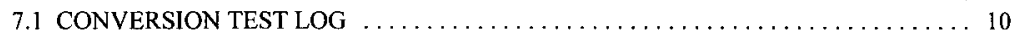

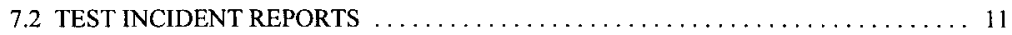

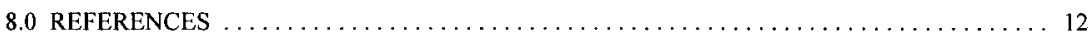

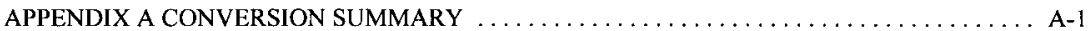

APPENDIX B DATABASE PROFILES $\ldots \ldots \ldots \ldots \ldots \ldots \ldots \ldots \ldots \ldots \ldots \ldots \ldots \ldots \ldots \ldots \ldots$

APPENDIX C DATABASE CONTENT DIFFERENCES $\ldots \ldots \ldots \ldots \ldots \ldots \ldots \ldots \ldots \ldots \ldots$ C-1 
HNF-SD-WM-TP-431 Rev. 3

\section{LIST OF TABLES}

1. Conversion to RDD-100 Version 4.1.1 Test Log 


\subsection{INTRODUCTION}

\subsection{PURPOSE}

A formal systems engineering approach has been adopted at Hanford for the development of major systems like the Tank Waste Remediation System (TWRS). This includes performing the activities of mission analysis, functional analysis, requirements analysis, parametric analysis, and alternative analysis. To manage complex sets of requirements, provide document traceability, and support a broad range of related systems engineering activities, a tool known within Westinghouse Hanford Company (WHC) as the Requirements Management and Assured Compliance System (RMACS) is used. The main software tool in the RMACS system is the RDD-100 software tool set developed by Ascent Logic Corporation (ALC). This tool set contains the systems engineering data describing the TWRS technical baseline. This document provides the test documentation required for the conversion between two versions of the RDD-100 software application, from Version 4.1 to Version 4.1.1. The testing performed specifically addresses the conversion of the data set between the two versions. The purpose of the test documentation is to verify that the data in the database has come through the conversion without becoming corrupted.

\subsection{SCOPE}

The testing is intended to confirm that the data converted and then stored in the new version of RDD-100 (Version 4.1.1) is identical to the data contained in the old version (Version 4.1). The RDD100 application is a commercial off-the-shelf software package that has been in use at Hanford for about 4 years. The new version (4.1.1) has been extensively tested by the developer, been in use at Hanford for about one month, and has been in use by other companies. Only representative testing of the applications input and output capabilities will be performed to make sure it continues to function as expected. Reports previously developed with the older version (4.1) of the RDD- 100 report writer were determined not to require formal conversion testing. The reports are always changing and are only used to query the data base and create specific views of the data to be printed in a report format. Also, any RDD-100 generated reports used to define a technical baseline are independently reviewed for correctness.

\subsection{OVERVIEW}

The U.S. Department of Energy (DOE) established the TWRS Program to safely manage and dispose of the tank waste stored at the Hanford Site. The scope of the TWRS Program and projects is to receive, safely store, maintain, treat, and dispose of tank waste. Tank waste includes the current contents of 149 Single-Shell Tanks (SSTs), 28 Double-Shell Tanks (DSTs), 47 miscellaneous tanks, new waste that may be added to these facilities, and all encapsulated cesium and strontium stored onsite and returned from offsite users.

The TWRS Program has adopted a systems engineering approach to integrate all activities necessary to build a system that achieves the tank waste remediation mission. The infrastructure framework being developed to enable effective deployment of systems engineering includes a set of computer-based tools to automate the process and manage information. The RMACS is one of the systems of computer-based tools being used to assist the TWRS management and engineers in the application of the systems engineering process to the TWRS domain. This system assists the systems 
engineer in evaluating, analyzing, grouping, connecting, categorizing, storing, and communicating information and data that relate to the tank waste system. As mentioned above, the RDD-100 software application is the main component of RMACS.

Currently TWRS is using RDD-100 Version 4.1. To effectively utilize the investment in RDD100 , upgrading to the current version of RDD, Version 4.1.1, is recommended. The original requirements that led to selecting RDD-100 to support the systems engineering activity and store the technical baseline for TWRS have not changed and are still satisfied by Version 4.1.1. This new version of RDD-100 (4.1.1) is a minor upgrade with most of the changes being fixes to known problems. Many of the features fixed in this new release are being used by the TWRS program. Some of the improvements are: 1) fixes errors in Report Writer margins and borders, 2) fixes all decomposable element types with regard to date/time stamp updates on TimeFunctions, 3) fixes problems with change bars in reports, 4) updates the MEV "print View" operation, and 5) fixes reordering problems with Completion Criteria. The product of the conversion activity is to successfully take the current TWRS technical baseline data stored in Version 4.1 and move it over to Version 4.1.1 without creating or losing any data element definitions or relationships between the elements.

\subsection{DEFINITIONS}

$\begin{array}{lll}\text { ALC - } & \text { Ascent Logic Corporation } \\ \text { DOE - } & \text { U.S. Department of Energy } \\ \text { DST - } & \text { Double-Shell Tank } \\ \text { HSTB - } & \text { Hanford Site Technical Baseline } \\ \text { RDD - } & \text { RDD-100/Requirements Driven Development } \\ \text { SST - } & \text { Single-Shell Tank } \\ \text { TWRS - } & \text { Tank Waste Remediation System }\end{array}$

\subsection{TEST PLAN}

\subsection{TEST ITEMS}

The TWRS systems engineering data contained in the RDD-100 database, in the form of Elements, Relations, and Attributes, will be tested to confirm the completeness and accuracy after the data is transferred to the new software version.

\subsection{FEATURES TO BE TESTED/NOT TO BE TESTED}

\section{Conversion Data:}

After the data stored in the RDD-100 database is transferred to the new software version, it will be checked manually to ensure that the new version contains the proper numbers of elements of each type, along with their relationships and attributes. The data will also be sampled to compare the two data sets and verify that there are no differences. 
RDD-100:

The RDD-100 Version 4.1.1 software application is a commercial product that was released about 4 months ago and has been used extensively by other companies. The product has been thoroughly tested and no further testing is required for this task. However, some representative testing of the software's input and output functions will be performed and reviewed as a result of the data conversion testing.

\subsection{TEST DELIVERABLES}

The test documentation will be contained in one document that defines the test plan, design, procedures, and results. The test results will include the following topics:

Test Logs

Test Incident Reports

Test Summary Reports

Test Output data

\subsection{ACCEPTANCE CRITERIA}

The individual pass/fail criteria described in Section 3.2 must all be satisfied in order for the conversion as a whole to be accepted.

\subsection{TESTING TASKS}

\section{Side-by-Side Execution:}

A set of updates to the RDD-100 data will be prepared for both versions.

Identical changes will be made to the data stored in both versions using the standard input interface.

The results will be compared manually based on the data collected automatically by the RDD- 100 generated reports described below.

\section{Data Count:}

A profiling report that will produce and output detailed counting results is needed for both versions of RDD- 100 .

Profiles will be produced for the data sets stored in each version.

The profiles will be compared manually to make sure the number counts for each element and associated relationships are the same. 


\section{Detailed Sampling:}

A database sampling report that will produce detailed output for a selected number (representative sample) of data items is needed for both versions of RDD- 100 .

The report will be run on both sets of data.

The output will be compared using the UNIX "diff' utility, which will output a file of the differences between the two data sets.

\subsection{ENVIRONMENTAL NEEDS}

The new version of the RDD-100 application has already been installed on a UNIX Sun ${ }^{2}$ server with the capability of checking out a license. At least one UNIX Sun station that runs the Solaris operating system is required to run the RDD-100 application and produce the reports. The UNJX station needs access to the Sun server over the Hanford Local Area Network (HLAN) to check out a license and to share data with other Sun stations on the network. There are no special security requirements.

\subsection{RESPONSIBILITIES}

Members of the TWRS Systems Application team and subcontractors are responsible for all areas of the testing.

\subsection{STAFFING AND TRAINING NEEDS}

- One project leader, in charge of the testing acceptance, timing, and task priorities.

- One test technician, to perform the tests and track progress on individual tests.

- One RDD-100 programmer, to generate the database profile reports for each version. The programmer could also perform the same duties as the test technician.

- These resources are available within the current RDD-100 user group.

\subsection{SCHEDULE}

The actual testing will take between one and four days, depending on the number and difficulty of the problems found with the converted data. It is expected, from preliminary tests that the difficulties will be few, minor, and easily resolved.

\footnotetext{
${ }^{1}$ UNIX is a registered trademark of UNIX System Laboratories, Inc.

${ }^{2}$ Sun is a trademark of Sun Microsystems, Inc.
} 


\subsection{RISKS AND CONTINGENCIES}

It is assumed that all of the data stored in the old version of RDD-100 will be converted to the new version without major difficulty. If difficulties are encountered, it is possible that the conversion effort will require a revision of the data storage structure, data, or some other modification. If this occurs, the old version of RDD-100 may still be used until the difficulties are resolved.

\subsection{TEST DESIGN}

\subsection{APPROACH}

The data stored in RDD-100 will be tested by running a database profile report for the data in both RDD versions. The profile report will contain counts of instances for each element type and their relationships.

\section{For all element types populated: \\ Number of instances. \\ Number of times each attribute is populated. \\ For all relationships populated: \\ Number of times each relationship is populated. \\ Number of times each target of the relationship is used.}

The data will also be tested by running a database sampler report on both sets of data. The output from the reports should be in the same format and should report on every element in the database. Then the output for the two sets will be compared using the UNIX "diff" utility.

A third test will round out the set by checking the input features, which are expected to function properly because they have been thoroughly tested by the vendor and other users. Changes will be made through the normal input function to identical data sets in both versions. The reports should yield results similar to those obtained for the first and second test case.

\subsection{ITEM PASS/FAIL CRITERIA}

The data transfer between versions will pass the test if the profile reports' output show that the two versions have identical profiles and the database sample reports have no differences as identified by the UNIX "diff" utility.

\subsection{SUSPENSION CRITERIA AND RESUMPTION REQUIREMENTS}

If the data stored in the new version of RDD are found to be different from that stored in the current version, the data testing will stop and will not resume until the reason for the difference is found. If necessary, a work-around path will be defined and testing resumed. 


\subsection{TEST CASES}

The test case format shall consist of a test case identifier, an explanation of the items being tested, input and output specifications, environmental needs, and any special requirements specific to that test case.

\subsection{TEST CASE IDENTIFIER}

The test cases will be identified by a short description of the testing that is to be performed. Only three test cases are considered necessary at this time: Database Statistics, Database Content, and Database Activity.

\subsection{TEST ITEMS}

\section{Database Statistics:}

This test case will compare the number of instances of each data type for the same data set stored in each of the two versions of RDD-100. The count comparisons will be for: the number of instances of each element type, the number of targets for each relationship available to each element type, and the number of each attribute available for each element type.

\section{Database Content:}

This test case will compare selected instances of the elements to make sure they are in the same order in each version of RDD-100 and that the names, numbers, and descriptions of the instances are identical.

\section{Database Activity:}

This test case will utilize the normal input features of RDD-100 to make changes to the data set in each version. Next a check will be made to make sure the data was changed and stored correctly in the new version by comparing the database profile reports for the two versions. The changes made to the database supporting the most recent change request package will be made in the new version and a database profile report will be run the make the comparison. This test is performed to round out the test set and check that the input function performs as expected. Because the software has been thoroughly tested by ALC and other users throughout the country, the results of the test are expected to be positive.

\subsection{INPUT SPECIFICATIONS}

For the first two test cases, the entire RDD-100 data set will be checked without using the standard input features. A data set stored in the old version of RDD-100 will be converted and stored in the new version. The resulting data set will be checked to make sure the conversion was a success. For the Database Activity test case, the normal input functions will be used to make the changes requested in the most recent change request package. 


\subsection{OUTPUT SPECIFICATIONS}

\section{Database Statistics:}

The output will be in the form of a table that provides a profile of the data set and sums the number of instances. The format is shown in the Appendix B, DATABASE PROFILE. The tables output by the two versions of RDD-100 will be compared to determine whether or not the statistics match.

\section{Database Content:}

The output will be in the form of an ASCII text file that consists of groupings of Name, Number, and Description for every instance of every element type in the data set. The files output by the two versions of RDD- 100 will be compared by the UNIX "diff" utility to determine whether or not there are any differences.

\section{Database Activity:}

The output will be two Database Profile reports, which contain the changes to the data set that were requested by the most recent change request package. Data structure profiles will be created for both versions of RDD-100. These two reports will be compared to see if the results are the same. Also the reports created before entering the changes will be compared to make sure both sets of results are consistent.

\subsection{SPECIAL REQUIREMENTS}

\section{Database Statistics:}

No special requirements.

\section{Database Content:}

No special requirements.

\section{Database Activity:}

No special requirements.

\subsection{INTERCASE DEPENDENCIES}

There are no true dependencies between the first two cases. It is recommended, however, that the Database Statistics test case be performed first, because if it fails, the Database Content test case is guaranteed to fail. There are no dependencies between the second and third cases. The first case must be passed before the third case will have any meaning.

\subsection{TEST PROCEDURES}

\section{Database Statistics:}

1. Log: See Section 7.1, Test Log.

2. Setup: RDD-100 must be started in each version using the appropriate data set.

3. Start: N/A 
4. Proceed: Print the Database Profile, (Appendix B) report in both versions of RDD-100 and compare the numbers to ensure that they match between the two data sets.

5. Measure: N/A

6. Shutdown: If it becomes necessary to suspend testing, there are no actions that are required to safely shut down.

7. Restart: Simply follow the Setup and Proceed procedures.

8. Stop: N/A

9. Contingencies: Any anomalous events will have to be evaluated before a response can be formulated. Anomalous events will be recorded on the test log and test incident reports (Section 7.2) will be generated to detail the event and its resolution.

\section{Database Content:}

1. Log: See attached Test Log.

2. Setup: RDD-100 must be started in each version using the appropriate data set.

3. Start: N/A

4. Proceed: Print the Database Sampler report in both versions of RDD-100 and compare the output using the UNIX "diff" utility.

5. Measure: N/A

6. Shutdown: If it becomes necessary to suspend testing, there are no actions that are required to safely shut down.

7. Restart: Simply follow the Setup and Proceed procedures.

8. Stop: N/A

9. Contingencies: Any anomalous events will have to be evaluated before a response can be formulated. Anomalous events will be recorded on the test $\log$ and test incident reports will be generated to detail the event and its resolution.

\section{Database Activity:}

1. Log: See attached Test Log.

2. Setup: RDD-100 must be started in each version using the appropriate data set.

3. Start: N/A

4. Proceed: Make changes to the data set stored in both versions of RDD-100 using the requested changes in the most recent change request package. Print the Database Profile report in both versions of RDD-100 and compare the numbers. The comparison results should be consistent with those obtained in the Database Statistics test case.

5. Measure: N/A

6. Shutdown: If it becomes necessary to suspend testing, there are no actions that are required to safely shut down.

7. Restart: Simply follow the Setup and Proceed procedures.

8. Stop: N/A

9. Contingencies: Any anomalous events will have to be evaluated before a response can be formulated. Anomalous events will be recorded on the test $\log$ and test incident reports will be generated to detail the event and its resolution. 


\subsection{TEST ITEM TRANSMITTAL LIST}

\subsection{TRANSMITTED ITEMS}

The TWRS technical baseline data used to produce the TWRS Functions and Requirements Document, WHC-SD-WM-FRD-020, Rev. 1, is stored in Version 4.0.3 of the RDD-100 system engineering software system. The master data set of the TWRS technical baseline, Revision 1, is stored on a Sun SPARC Server named twrsse. The computer files containing this version of the technical baseline are detailed in the Supporting Document "Tank Waste Remediation Systems Technical Baseline Database," document number WHC-SD-WM-CSWD-079, Rev. 1. The master data set was converted to the new version of RDD-100 (4.1.1) and tested.

In June of 1996 testing to upgrade from RDD-100 Version 4.0.3 to Version 4.1 was completed and documented (Revision 2 of this document). Since that time both versions of the RDD- 100 application have been used by the TWRS project. The purpose of this document is to test and document the upgrade from RDD-100 Version 4.1 to 4.1.1. Since the current TWRS master data set is stored in Version 4.0.3, an intermediate conversion of the data set was performed to Version 4.1. As in the original testing (Revision 2 of this document), no discrepancies were found in going from Version 4.0.3 to Version 4.1. The results of this intermediate conversion are covered by Revision 2 of this document and will not be repeated in this revision.

Two pending changes to the Rev. 1 technical baseline have been made using the 4.0.3 version of RDD100. These change files (RDD-100 delta files) were used in the "database activity" testing. The delta files were obtained from the TWRS RDD-100 System Administrator. No conversion was necessary since Versions 4.0.3, 4.1, and 4.1.1 all have the same format.

The list of files used in the testing, their full path, and the computer system they reside on are contained in the next section.

\subsection{LOCATION}

All items used in testing the new version of RDD-100 are files stored on Sun workstations. The Sun workstations containing the original files and the files used in test work area are designated by name as follows:

Sun SPARC ${ }^{3}$ Server 1000 - twrsse

Sun SPARC 10/41 - electro (Tester)

Sun SPARC 10/41 - tootsie (Tester)

The master image file containing the technical baseline:

(Version 4.0.3): twrsse:/export/rdd/conversion/41 to41 1/TWRS-Rev1-Pending-093096.im

(Version 4.1): twrsse:/export/rdd/conversion/41 to411/V41-TWRS-Rev1-Pending-093096.im

The RDD-100 Version 4.0.3/4.1/4.1.1 change files:

directory: twrsse:/export/rdd/conversion/4l to $411 /$

files: TWR-97-201.rdt TWR-97-202.rdt

${ }^{3}$ SPARC is a trademark of SPARC International, Inc. 
The Revision 1 technical baseline converted to Version 4.1.1:

twrsse:/export/rdd/conversion/4 I to4 I l/V4 I 1-TWRS-Rev1-Pending-093096.im

The reports used for the testing:

$\begin{array}{lll}\text { directory: } & \text { twrsse:/export/rdd/conversion/41to411/ } \\ \text { files: } & \text { V41-DatabaseProfile.rpt } & \text { DatabaseSampler.403.rpt } \\ & \text { V411-DatabaseProfile.rpt } & \end{array}$

The output from the reports:

directory: twrsse:/export/rdd/conversion/41 to 411 /

files: V41-TWRS-Rev1-Pending-093096Database_Profile.ps

V41-TWRS-Rev1-Pending-093096+crsDatabase_Profile.ps

V41-TWRS-Rev1-Pending-093096Database_Sampler.asc

V41-TWRS-Rev1-Pending-093096+crsDatabase_Sampler.asc

V411-TWRS-Rev1-Pending-093096Database_Profile.ps

V411-TWRS-Rev1-Pending-093096+crsDatabase_Profile.ps

V411-TWRS-Rev1-Pending-093096Database_Sampler.asc

V411-TWRS-Revi-Pending-093096+crsDatabase_Sampler.asc

\subsection{STATUS}

All of the items transmitted are configured as expected and do not result in any deviations to the test plan.

\subsection{TEST RESULTS}

The test results are separated into four main pieces.

1) A summary of the testing performed to verify that the upgrade to a new version of RDD-100 was successful is contained in Appendix A.

2) The database profile tables showing element and relationship counts for four separate images are contained in Appendix B.

3) The report showing database content differences is contained in Appendix C.

4) The test log and incident reports are contained in the sections below.

\subsection{CONVERSION TEST LOG}

This section summarizes any test anomalies that are written up in a test incident report. The summary is contained in a test $\log$ (Table 1). A test witness was not considered necessary for this testing activity and, therefore, was left out of the test log. 
HNF-SD-WM-TP-431 Rev. 3

Table 1. Conversion to RDD-100 Version 4.1.1 Test Log

\begin{tabular}{|l|l|l|l|}
\hline Test Case & Pass/Fail & Incident Number or Comment & Signature/Date: \\
\hline $\begin{array}{l}\text { Database } \\
\text { Statistics }\end{array}$ & Pass & $\begin{array}{l}\text { See Appendix B, Database Profile for images: } \\
\text { V41-TWRS-Rev1-Pending-093096.im (p. B-2) } \\
\text { V411-TWRS-Rev1-Pending-093096.im (p. B-12) }\end{array}$ & $\begin{array}{l}\text { Test Performer: } \\
\text { Jack C. Danley }\end{array}$ \\
\hline $\begin{array}{l}\text { Database } \\
\text { Content }\end{array}$ & Pass & See Appendix C & $\begin{array}{l}\text { Test Performer: } \\
\text { Jack C. Danley }\end{array}$ \\
\hline $\begin{array}{l}\text { Database } \\
\text { Activity }\end{array}$ & Pass & $\begin{array}{l}\text { See Appendix B, Database Profile for images: } \\
\text { V41-TWRS-Rev1-Pending-093096+crs.im (p. B-19) }\end{array}$ & $\begin{array}{l}\text { Test Performer: } \\
\text { Jack C. Danley }\end{array}$ \\
\hline
\end{tabular}

\subsection{TEST INCIDENT REPORTS}

There were no incidents which occurred during the testing. 
HNF-SD-WM-TP-431 Rev. 3

\subsection{REFERENCES}

The following documents were used as sources of information for the test plan.

ANSI/IEEE 829-1983, Standard for Software Test Documentation, IEEE, 1983.

ANSI/IEEE 1008-1987, Standard for Software Unit Testing, IEEE, 1987.

Walker, Kevin G, Test Plan for the Integrated Dynamic Modeling and Management System (IDMMS), LATA, April 26, 1995.

WHC-CM-3-10, Software Practices, WHC, January 31, 1993

WHC-SD-WM-FRD-020, Rev. 1, Tank Waste Remediation System Functions and Requirements Document, WHC, September 30, 1996.

WHC-SD-WM-CSWD-079, Rev. 1, Tank Waste Remediation Systems Technical Baseline Database, WHC, October 9, 1996. 


\section{APPENDIX A}

\section{CONVERSION TEST SUMMARY}

\subsection{Summary}

The testing confirmed that conversion of the TWRS technical baseline data from Version 4.1 to Version 4.1.I of RDD-100 was successful. None of the three test cases showed any inconsistencies between the data in RDD-100 Version 4.1 and Version 4.1.1. The data was tested to be certain that the number of elements, relations and attributes of each type matched, that the name, number and description matched between the two versions, and to provide user confidence in the compatibility between the two versions. The testing was performed by Jack Danley on a SUN ${ }^{4}$ SPARC 10 computer over the course of several days. The data files can be found, along with the reports and output from the reports as referenced in Section 6.2 above.

\subsection{Variances}

None

\subsection{Comprehensive Assessment}

The testing process was reasonably comprehensive, as it checks almost every aspect of the data transferred. Two aspects were not directly tested. First, some of the attributes were not tested to determine if they contain the correct data; however, the number of times the attributes were populated was checked. Secondly, only spot checks were made to determine if relationships were still associated with the correct elements. The extra effort of manually performing this check on all relationships was not considered necessary, since the count for each set of relationships and elements was correct and the conversion routines in RDD-100 Version 4.1.1 have had ample time to be thoroughly tested by the vendor and users.

\subsection{Summary of Results}

Results from the three test cases showed no differences between the two versions of RDD-100.

\subsection{Evaluation}

The test results show that the data conversion was a success and the new version of RDD100 can be used to manage the TWRS technical baseline.

\footnotetext{
${ }^{4}$ SUN is a trademark of SUN Microsystems, Inc.
} 
HNF-SD-WM-TP-431 Rev. 3

\subsection{Summary of Activities}

The major testing activities were running the database query reports and performing the documentation to support the conversion. Running the queries and resolving incidents took two days. Documenting the entire process took approximately two days. The total resource usage for the project was about one week of user and machine time, with the total time elapsed from start of the process to the end being two weeks because of other work intervening. 
HNF-SD-WM-TP-431 Rev. 3

APPENDIX B

\section{DATABASE PROFILES}

B-1 
HNF-SD-WM-TP-431 Rev. 3

\section{DATABASE PROFILE}

of

Facility: DOE

V41-TWRS-Rev1-Pending-093096.im

\section{1:34:39 pm}

Prepared By:

TWRS Systems Engineering 
HNF-SD-WM-TP-431 Rev. 3

TABLE 1 DOE Relationships

\begin{tabular}{|c|c|c|c|}
\hline ELEMENT TYPE* & INSTANCES & RELATIONSHIP NAME & RELATIONSHIPS \\
\hline \multirow[t]{19}{*}{ SystemRequirement } & \multirow[t]{19}{*}{1660} & \multirow[t]{9}{*}{ traces to } & Component 487 \\
\hline & & & Criticallssue 5 \\
\hline & & & Decision 64 \\
\hline & & & Interface 28 \\
\hline & & & ItemLink 34 \\
\hline & & & RequiredAnalysis 1 \\
\hline & & & Source 4 \\
\hline & & & TimeFunction 5107 \\
\hline & & & TimeItem 2299 \\
\hline & & primary is & Organization 139 \\
\hline & & documented by & Source 1358 \\
\hline & & annotated by & Comment 151 \\
\hline & & invokes & Source 10 \\
\hline & & categorized by & Category 2221 \\
\hline & & incorporated by & SystemRequirement 1070 \\
\hline & & incorporates & SystemRequirement $\quad 1070$ \\
\hline & & verified by & VerificationRequirement 27 \\
\hline & & traced from & Criticallssue 359 \\
\hline & & & Decision 98 \\
\hline TimeItem & 898 & output from & TimeFunction 939 \\
\hline & & documented by & Source 1 \\
\hline & & traced from & Criticallssue 179 \\
\hline
\end{tabular}

* Element Types with no instances are not listed. Element types are sorted by the number of instances. 
TABLE 1 DOE Relationships

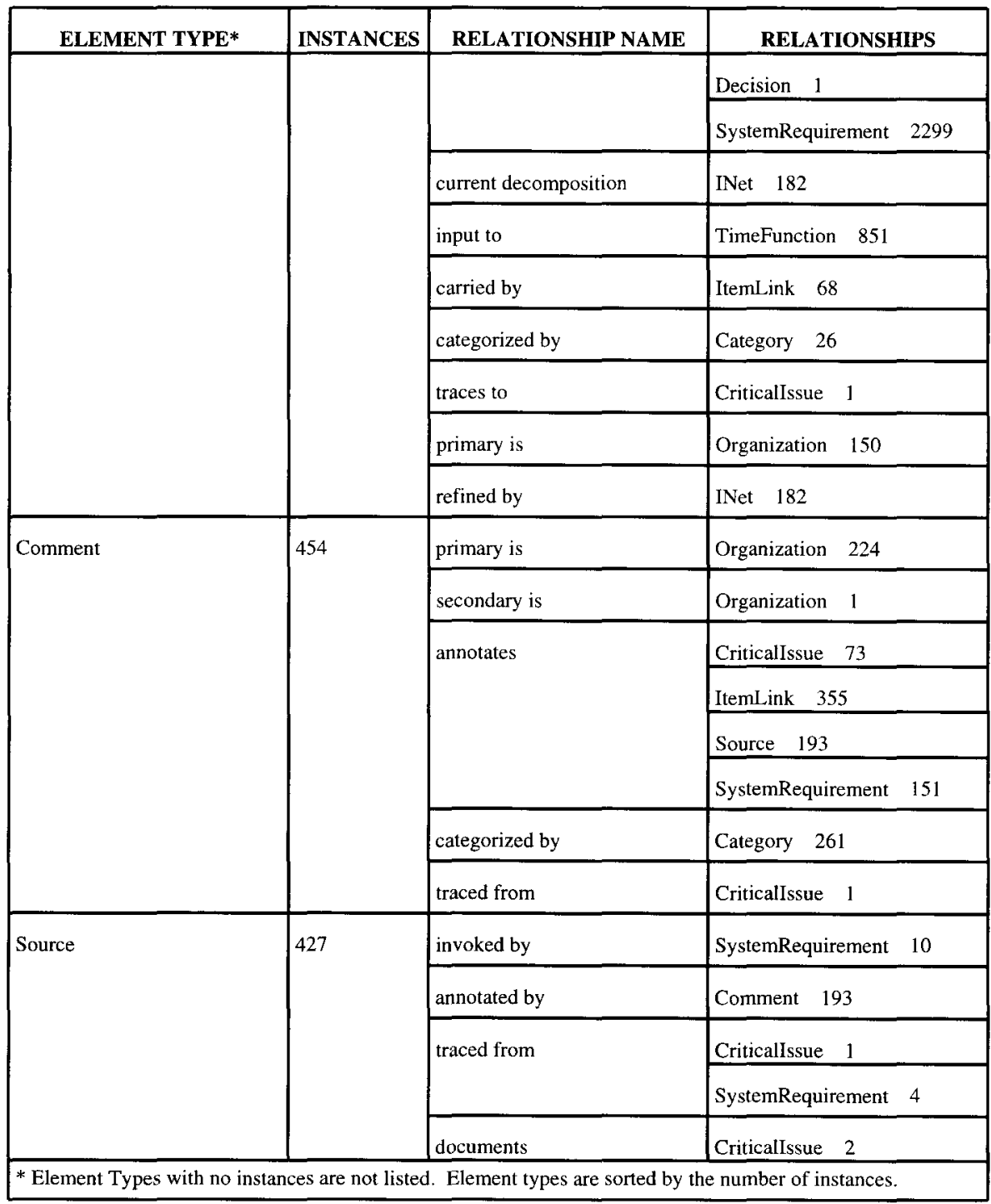


TABLE 1 DOE Relationships

\begin{tabular}{|c|c|c|c|}
\hline ELEMENT TYPE* & INSTANCES & RELATIONSHIP NAME & RELATIONSHIPS \\
\hline & & & Decision 161 \\
\hline & & & Required Analysis 7 \\
\hline & & & SystemRequirement 1358 \\
\hline & & & Timeltem 1 \\
\hline \multirow[t]{19}{*}{ CriticalIssue } & \multirow[t]{19}{*}{421} & primary is & Organization 193 \\
\hline & & documented by & Source 2 \\
\hline & & annotated by & Comment 73 \\
\hline & & analyzed by & RequiredAnalysis 292 \\
\hline & & categorized by & Category 1 \\
\hline & & \multirow[t]{10}{*}{ traces to } & Comment 1 \\
\hline & & & Component 8 \\
\hline & & & CriticalIssue 2 \\
\hline & & & Decision 2 \\
\hline & & & Interface 92 \\
\hline & & & RequiredAnalysis 1 \\
\hline & & & Source 1 \\
\hline & & & SystemRequirement 359 \\
\hline & & & TimeFunction 30 \\
\hline & & & TimeItem 179 \\
\hline & & \multirow[t]{4}{*}{ traced from } & \begin{tabular}{|l} 
CriticalIssue $\quad 2$ \\
\end{tabular} \\
\hline & & & Decision 113 \\
\hline & & & SystemRequirement 5 \\
\hline & & & TimeItem 1 \\
\hline
\end{tabular}


TABLE 1 DOE Relationships

\begin{tabular}{|c|c|c|c|}
\hline ELEMENT TYPE* & INSTANCES & RELATIONSHIP NAME & RELATIONSHIPS \\
\hline & & \multirow[t]{2}{*}{ raised by } & Component 6 \\
\hline & & & TimeFunction 6 \\
\hline \multirow[t]{8}{*}{ RequiredAnalysis } & \multirow[t]{8}{*}{364} & documented by & Source 7 \\
\hline & & primary is & Organization 186 \\
\hline & & secondary is & Organization 4 \\
\hline & & \multirow[t]{2}{*}{ analyzes } & CriticalIssue 292 \\
\hline & & & Decision 55 \\
\hline & & \multirow[t]{3}{*}{ traced from } & CriticalIssue 1 \\
\hline & & & Decision 1 \\
\hline & & & SystemRequirement 1 \\
\hline \multirow[t]{10}{*}{ TimeFunction } & \multirow[t]{10}{*}{326} & inputs & TimeItem 851 \\
\hline & & outputs & TimeItem 939 \\
\hline & & primary is & Organization 41 \\
\hline & & current decomposition & FNet 77 \\
\hline & & \multirow[t]{2}{*}{ performed by } & Component 18 \\
\hline & & & System 1 \\
\hline & & decomposed by & FNet 78 \\
\hline & & \multirow[t]{2}{*}{ traced from } & CriticalIssue 30 \\
\hline & & & SystemRequirement 5107 \\
\hline & & raises & CriticalIssue 6 \\
\hline \multirow[t]{2}{*}{ Decision } & \multirow[t]{2}{*}{248} & categorized by & Category 4 \\
\hline & & traces to & Component 45 \\
\hline
\end{tabular}


HNF-SD-WM-TP-431 Rev. 3

TABLE 1 DOE Relationships

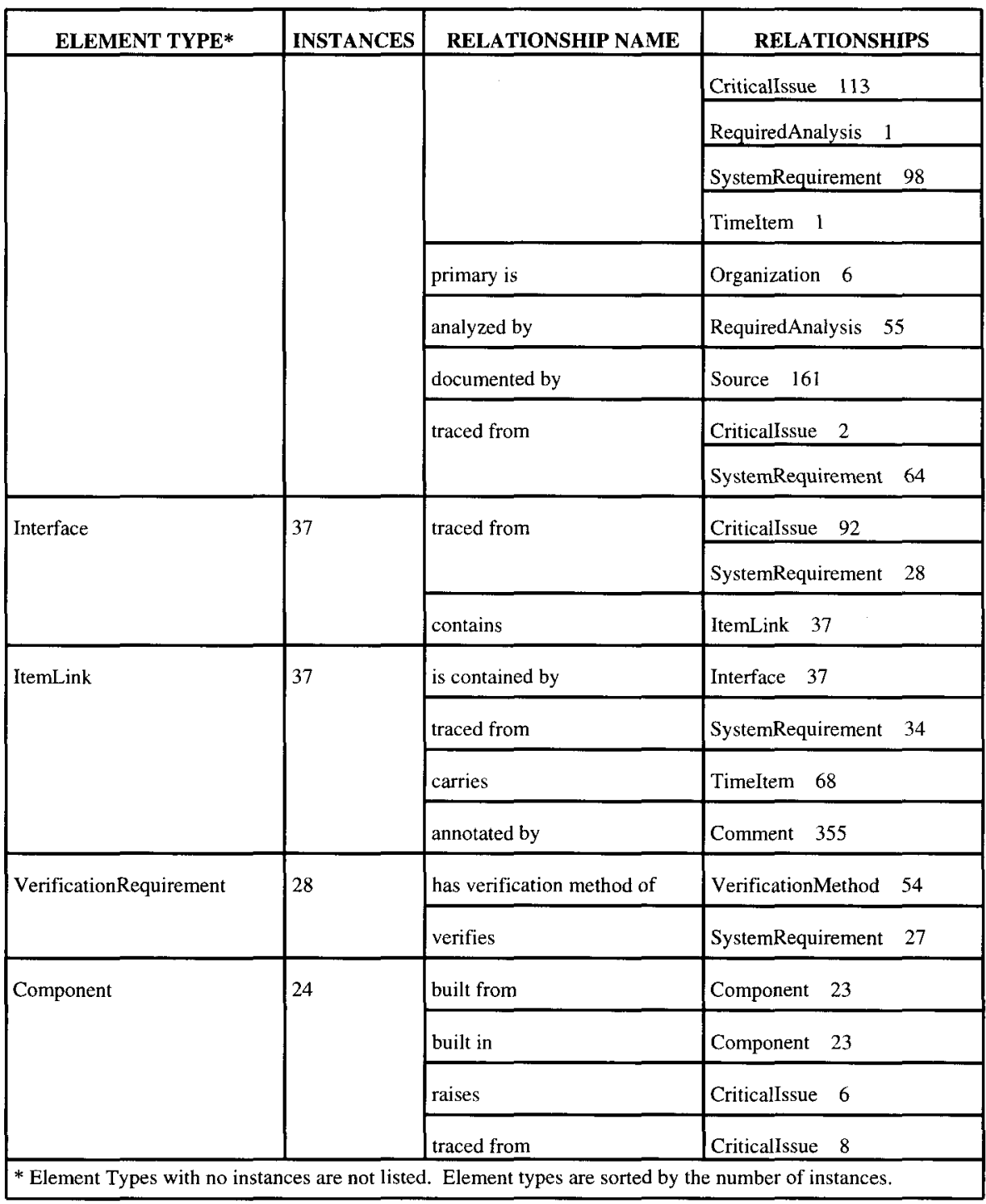


HNF-SD-WM-TP-431 Rev. 3

TABLE 1 DOE Relationships

\begin{tabular}{|c|c|c|c|}
\hline \multirow{4}{*}{ ELEMENT TYPE* } & INSTANCES & RELATIONSHIP NAME & RELATIONSHIPS \\
\hline & & & Decision 45 \\
\hline & & & SystemRequirement 487 \\
\hline & & performs & TimeFunction 18 \\
\hline \multirow[t]{9}{*}{ Organization } & \multirow[t]{9}{*}{20} & \multirow[t]{7}{*}{ primary for } & Comment 224 \\
\hline & & & Criticallssue 193 \\
\hline & & & Decision 6 \\
\hline & & & RequiredAnalysis $\quad 186$ \\
\hline & & & SystemRequirement 139 \\
\hline & & & TimeFunction 41 \\
\hline & & & TimeItem 150 \\
\hline & & \multirow[t]{2}{*}{ secondary for } & Comment 1 \\
\hline & & & RequiredAnalysis 4 \\
\hline \multirow[t]{5}{*}{ Category } & \multirow[t]{5}{*}{16} & \multirow[t]{5}{*}{ categorizes } & Comment 261 \\
\hline & & & CriticalIssue 1 \\
\hline & & & Decision 4 \\
\hline & & & SystemRequirement 2221 \\
\hline & & & TimeItem 26 \\
\hline VerificationMethod & 5 & verification method for & VerificationRequirement 54 \\
\hline
\end{tabular}


HNF-SD-WM-TP-431 Rev. 3

TABLE 2 DOE Attributes

\begin{tabular}{|c|c|c|c|}
\hline ELEMENT TYPE* & INSTANCES & ATTRIBUTE NAME & ATTRIBUTES \\
\hline \multirow[t]{5}{*}{ SystemRequirement } & \multirow[t]{5}{*}{1660} & Number & 1262 \\
\hline & & Line Number & 1 \\
\hline & & Paragraph Title & 64 \\
\hline & & Status & Pending: 1 \\
\hline & & Description & 1585 \\
\hline \multirow[t]{5}{*}{ TimeItem } & \multirow[t]{5}{*}{898} & Number & 44 \\
\hline & & Message Priority & 898 \\
\hline & & Description & 882 \\
\hline & & Size & 898 \\
\hline & & IDEF0 Type & input: 898 \\
\hline \multirow[t]{2}{*}{ Comment } & \multirow[t]{2}{*}{454} & Description & 454 \\
\hline & & Number & 98 \\
\hline \multirow[t]{8}{*}{ Source } & \multirow[t]{8}{*}{427} & Description & 327 \\
\hline & & Abbreviation & 1 \\
\hline & & Number & 40 \\
\hline & & \multirow[t]{5}{*}{ Source Type } & $\begin{array}{l}\text { Originating Requirements: } \\
218\end{array}$ \\
\hline & & & Meeting Minutes: 1 \\
\hline & & & Trade-off Study Report: 4 \\
\hline & & & Project Memo: 6 \\
\hline & & & Standard: 3 \\
\hline \multirow[t]{4}{*}{ CriticalIssue } & \multirow[t]{4}{*}{421} & \multirow[t]{2}{*}{ Issue Type } & Issue: 418 \\
\hline & & & Required Analysis: 3 \\
\hline & & Due Date . & 148 \\
\hline & & Priority & A (Very High): 13 \\
\hline
\end{tabular}

* Element Types with no instances are not listed. Element types are sorted by the number of instances. 
HNF-SD-WM-TP-431 Rev. 3

TABLE 2 DOE Attributes

\begin{tabular}{|c|c|c|c|}
\hline ELEMENT TYPE* & INSTANCES & ATTRIBUTE NAME & ATTRIBUTES \\
\hline & & Actual Date & 36 \\
\hline & & Description & 418 \\
\hline & & Number & 165 \\
\hline \multirow[t]{2}{*}{ RequiredAnalysis } & \multirow[t]{2}{*}{364} & Description & 357 \\
\hline & & Number & 174 \\
\hline \multirow[t]{4}{*}{ TimeFunction } & \multirow[t]{4}{*}{326} & Description & 316 \\
\hline & & Number & 324 \\
\hline & & Debugging Mode & none: 326 \\
\hline & & Execution Level & follow decomposition: 326 \\
\hline \multirow[t]{8}{*}{ Decision } & \multirow[t]{8}{*}{248} & Alternatives & 57 \\
\hline & & Problem & 2 \\
\hline & & Choice & 94 \\
\hline & & \multirow[t]{3}{*}{ Status } & Open: 4 \\
\hline & & & Enabling Assumption: 38 \\
\hline & & & Resolved: 103 \\
\hline & & Description & 139 \\
\hline & & Number & 127 \\
\hline \multirow[t]{2}{*}{ Interface } & \multirow[t]{2}{*}{37} & Description & 22 \\
\hline & & Number & 37 \\
\hline \multirow[t]{3}{*}{ ItemLink } & \multirow[t]{3}{*}{37} & Is Constrained & false: 37 \\
\hline & & Number & 37 \\
\hline & & Abbreviation & 37 \\
\hline VerificationRequirement & 28 & & \\
\hline Component & 24 & Component Type & System: 1 \\
\hline
\end{tabular}


HNF-SD-WM-TP-431 Rev. 3

TABLE 2 DOE Attributes

\begin{tabular}{|l|l|l|l|}
\hline \multirow{2}{*}{ ELEMENT TYPE* } & INSTANCES & \multicolumn{1}{|c|}{ ATTRIBUTE NAME } & \multicolumn{1}{c|}{ ATTRIBUTES } \\
\hline \multirow{2}{*}{} & & & System Segment: 18 \\
\cline { 3 - 4 } & & Description & 24 \\
\cline { 3 - 4 } & & Number & 24 \\
\hline Organization & 20 & Abbreviation & 5 \\
\hline \multirow{2}{*}{ Category } & 16 & Description & 8 \\
\cline { 3 - 4 } & & Number & 4 \\
\hline VerificationMethod & 5 & & \\
\hline * Element Types with no instances are not listed. Element types are sorted by the number of instances.
\end{tabular}




$$
\text { HNF-SD-WM-TP-431 Rev. } 3
$$

\section{DATABASE PROFILE}

$$
\text { of }
$$

Facility: DOE

V411-TWRS-Rev1-Pending-093096.im

\section{1:18:39 pm}

\section{Prepared By:}

TWRS Systems Engineering 
HNF-SD-WM-TP-431 Rev, 3

TABLE 1 DOE Relationships

\begin{tabular}{|c|c|c|c|}
\hline ELEMENT TYPE* & INSTANCES & RELATIONSHIP NAME & RELATIONSHIPS \\
\hline \multirow[t]{19}{*}{ SystemRequirement } & \multirow[t]{19}{*}{1660} & documented by & Source 1358 \\
\hline & & verified by & VerificationRequirement 27 \\
\hline & & annotated by & Comment 151 \\
\hline & & primary is & Organization 139 \\
\hline & & \multirow[t]{2}{*}{ traced from } & CriticalIssue 359 \\
\hline & & & Decision 98 \\
\hline & & \multirow[t]{9}{*}{ traces to } & \begin{tabular}{|ll} 
Component 487 \\
\end{tabular} \\
\hline & & & \begin{tabular}{|l} 
CriticalIssue 5 \\
\end{tabular} \\
\hline & & & \begin{tabular}{|l} 
Decision 64 \\
\end{tabular} \\
\hline & & & Interface 28 \\
\hline & & & \begin{tabular}{|ll} 
ItemLink 34 \\
\end{tabular} \\
\hline & & & RequiredAnalysis 1 \\
\hline & & & Source 4 \\
\hline & & & TimeFunction 5107 \\
\hline & & & TimeItem 2265 \\
\hline & & invokes & Source 10 \\
\hline & & categorized by & Category 2221 \\
\hline & & incorporated by & SystemRequirement 1070 \\
\hline & & incorporates & SystemRequirement 1070 \\
\hline \multirow[t]{12}{*}{ TimeItem } & \multirow[t]{12}{*}{881} & refined by & INet 181 \\
\hline & & carried by & ItemLink 66 \\
\hline & & primary is & Organization 150 \\
\hline & & current decomposition & INet 181 \\
\hline & & traces to & CriticalIssue 1 \\
\hline & & documented by & Source 1 \\
\hline & & output from & TimeFunction 921 \\
\hline & & traced from & \begin{tabular}{|l} 
Criticallssue 179 \\
\end{tabular} \\
\hline & & & Decision 1 \\
\hline & & & SystemRequirement 2265 \\
\hline & & input to & TimeFunction 843 \\
\hline & & categorized by & Category 26 \\
\hline Comment & 454 & annotates & Criticallssue 73 \\
\hline
\end{tabular}


TABLE 1 DOE Relationships

\begin{tabular}{|c|c|c|c|}
\hline ELEMENT TYPE* & INSTANCES & RELATIONSHIP NAME & RELATIONSHIPS \\
\hline & & & ItemLink 355 \\
\hline & & & Source 193 \\
\hline & & & SystemRequirement 151 \\
\hline & & secondary is & Organization 1 \\
\hline & & primary is & Organization 224 \\
\hline & & categorized by & Category 261 \\
\hline & & traced from & CriticalIssue 1 \\
\hline \multirow[t]{9}{*}{ Source } & \multirow[t]{9}{*}{427} & \multirow[t]{2}{*}{ traced from } & Criticallssue 1 \\
\hline & & & SystemRequirement 4 \\
\hline & & \multirow[t]{5}{*}{ documents } & Criticallssue 2 \\
\hline & & & Decision 161 \\
\hline & & & RequiredAnalysis 7 \\
\hline & & & SystemRequirement 1358 \\
\hline & & & TimeItem 1 \\
\hline & & annotated by & Comment 193 \\
\hline & & invoked by & SystemRequirement 10 \\
\hline \multirow[t]{17}{*}{ Criticallssue } & \multirow[t]{17}{*}{421} & analyzed by & RequiredAnalysis 292 \\
\hline & & documented by & Source 2 \\
\hline & & annotated by & Comment 73 \\
\hline & & \multirow[t]{2}{*}{ raised by } & Component 6 \\
\hline & & & TimeFunction 6 \\
\hline & & primary is & Organization 193 \\
\hline & & \multirow[t]{4}{*}{ traced from } & Criticallssue 2 \\
\hline & & & Decision 113 \\
\hline & & & SystemRequirement 5 \\
\hline & & & TimeItem 1 \\
\hline & & categorized by & Category 1 \\
\hline & & \multirow[t]{6}{*}{ traces to } & Comment 1 \\
\hline & & & Component 8 \\
\hline & & & Criticallssue 2 \\
\hline & & & Decision 2 \\
\hline & & & Interface 92 \\
\hline & & & RequiredAnalysis 1 \\
\hline
\end{tabular}


TABLE 1 DOE Relationships

\begin{tabular}{|c|c|c|c|}
\hline ELEMENT TYPE* & INSTANCES & RELATIONSHIP NAME & RELATIONSHIPS \\
\hline & & & Source 1 \\
\hline & & & SystemRequirement 359 \\
\hline & & & TimeFunction 30 \\
\hline & & & Timeltem 179 \\
\hline \multirow[t]{8}{*}{ RequiredAnalysis } & \multirow[t]{8}{*}{364} & secondary is & Organization 4 \\
\hline & & documented by & Source 7 \\
\hline & & \multirow[t]{3}{*}{ traced from } & CriticalIssue 1 \\
\hline & & & Decision 1 \\
\hline & & & SystemRequirement 1 \\
\hline & & \multirow[t]{2}{*}{ analyzes } & CriticalIssue 292 \\
\hline & & & Decision 55 \\
\hline & & primary is & Organization 186 \\
\hline \multirow[t]{10}{*}{ TimeFunction } & \multirow[t]{10}{*}{326} & \multirow[t]{2}{*}{ traced from } & CriticalIssue 30 \\
\hline & & & SystemRequirement 5107 \\
\hline & & outputs & TimeItem 921 \\
\hline & & \multirow[t]{2}{*}{ performed by } & Component 18 \\
\hline & & & System 1 \\
\hline & & decomposed by & FNet 78 \\
\hline & & raises & CriticalIssue 6 \\
\hline & & primary is & Organization 41 \\
\hline & & inputs & TimeItem 843 \\
\hline & & current decomposition & FNet 77 \\
\hline \multirow[t]{11}{*}{ Decision } & \multirow[t]{11}{*}{248} & analyzed by & RequiredAnalysis 55 \\
\hline & & categorized by & Category 4 \\
\hline & & primary is & Organization 6 \\
\hline & & \multirow[t]{5}{*}{ traces to } & Component 45 \\
\hline & & & Criticallssue 113 \\
\hline & & & RequiredAnalysis 1 \\
\hline & & & SystemRequirement 98 \\
\hline & & & TimeItem 1 \\
\hline & & documented by & Source 161 \\
\hline & & \multirow[t]{2}{*}{ traced from } & CriticalIssue 2 \\
\hline & & & SystemRequirement 64 \\
\hline
\end{tabular}


HNF-SD-WM-TP-431 Rev. 3

TABLE 1 DOE Relationships

\begin{tabular}{|c|c|c|c|}
\hline ELEMENT TYPE* & INSTANCES & RELATIONSHIP NAME & RELATIONSHIPS \\
\hline \multirow[t]{3}{*}{ Interface } & \multirow[t]{3}{*}{37} & contains & ItemLink 37 \\
\hline & & \multirow[t]{2}{*}{ traced from } & CriticalIssue 92 \\
\hline & & & SystemRequirement 28 \\
\hline \multirow[t]{4}{*}{ ItemLink } & \multirow[t]{4}{*}{37} & carries & Timeltem 66 \\
\hline & & is contained by & Interface 37 \\
\hline & & annotated by & Comment 355 \\
\hline & & traced from & SystemRequirement 34 \\
\hline \multirow[t]{2}{*}{ VerificationRequirement } & \multirow[t]{2}{*}{28} & has verification method of & VerificationMethod 54 \\
\hline & & verifies & SystemRequirement 27 \\
\hline \multirow[t]{7}{*}{ Component } & \multirow[t]{7}{*}{24} & performs & TimeFunction 18 \\
\hline & & \multirow[t]{3}{*}{ traced from } & CriticalIssue 8 \\
\hline & & & Decision 45 \\
\hline & & & SystemRequirement 487 \\
\hline & & built from & Component 23 \\
\hline & & built in & Component 23 \\
\hline & & raises & CriticalIssue 6 \\
\hline \multirow[t]{9}{*}{ Organization } & \multirow[t]{9}{*}{20} & \multirow[t]{7}{*}{ primary for } & Comment 224 \\
\hline & & & Criticallssue 193 \\
\hline & & & Decision 6 \\
\hline & & & \begin{tabular}{|l} 
RequiredAnalysis 186 \\
\end{tabular} \\
\hline & & & SystemRequirement 139 \\
\hline & & & TimeFunction 41 \\
\hline & & & TimeItem 150 \\
\hline & & \multirow[t]{2}{*}{ secondary for } & Comment 1 \\
\hline & & & RequiredAnalysis 4 \\
\hline \multirow[t]{5}{*}{ Category } & \multirow[t]{5}{*}{16} & categorizes & Comment 261 \\
\hline & & & Criticallssue 1 \\
\hline & & & Decision 4 \\
\hline & & & SystemRequirement 2221 \\
\hline & & & TimeItem 26 \\
\hline VerificationMethod & 5 & verification method for & VerificationRequirement 54 \\
\hline
\end{tabular}


HNF-SD-WM-TP-431 Rev. 3

TABLE 2 DOE Attributes

\begin{tabular}{|c|c|c|c|}
\hline ELEMENT TYPE* & INSTANCES & ATTRIBUTE NAME & ATTRIBUTES \\
\hline \multirow[t]{5}{*}{ SystemRequirement } & \multirow[t]{5}{*}{1660} & Paragraph Title & 64 \\
\hline & & Status & Pending: 1 \\
\hline & & Description & 1585 \\
\hline & & Number & 1262 \\
\hline & & Line Number & 1 \\
\hline \multirow[t]{5}{*}{ TimeItem } & \multirow[t]{5}{*}{881} & Description & 865 \\
\hline & & Message Priority & 881 \\
\hline & & Size & 881 \\
\hline & & Number & 42 \\
\hline & & IDEF0 Type & input: 881 \\
\hline \multirow[t]{2}{*}{ Comment } & \multirow[t]{2}{*}{454} & Number & 98 \\
\hline & & Description & 454 \\
\hline \multirow[t]{8}{*}{ Source } & \multirow[t]{8}{*}{427} & Abbreviation & 1 \\
\hline & & Number & 40 \\
\hline & & Description & 327 \\
\hline & & \multirow[t]{5}{*}{ Source Type } & $\begin{array}{l}\text { Originating Requirements: } \\
218\end{array}$ \\
\hline & & & Meeting Minutes: 1 \\
\hline & & & Trade-off Study Report: 4 \\
\hline & & & Project Memo: 6 \\
\hline & & & Standard: 3 \\
\hline \multirow[t]{7}{*}{ CriticalIssue } & \multirow[t]{7}{*}{421} & Priority & A (Very High): 13 \\
\hline & & Description & 418 \\
\hline & & Actual Date & 36 \\
\hline & & \multirow[t]{2}{*}{ Issue Type } & Issue: 418 \\
\hline & & & Required Analysis: 3 \\
\hline & & Due Date & 148 \\
\hline & & Number & 165 \\
\hline \multirow[t]{2}{*}{ RequiredAnalysis } & \multirow[t]{2}{*}{364} & Description & 357 \\
\hline & & Number & 174 \\
\hline \multirow[t]{4}{*}{ TimeFunction } & \multirow[t]{4}{*}{326} & Debugging Mode & none: 326 \\
\hline & & Description & 316 \\
\hline & & Number & 324 \\
\hline & & Execution Level & follow decomposition: 326 \\
\hline \multirow[t]{3}{*}{ Decision } & \multirow[t]{3}{*}{248} & Problem & 2 \\
\hline & & Description & 139 \\
\hline & & Choice & 94 \\
\hline
\end{tabular}

* Element Types with no instances are not listed. Element types are sorted by the number of instances. 
TABLE 2 DOE Attributes

\begin{tabular}{|c|c|c|c|}
\hline ELEMENT TYPE* & INSTANCES & ATTRIBUTE NAME & ATTRIBUTES \\
\hline & & \multirow[t]{3}{*}{ Status } & Open: 4 \\
\hline & & & Enabling Assumption: 38 \\
\hline & & & Resolved: 103 \\
\hline & & Alternatives & 57 \\
\hline & & Number & 127 \\
\hline \multirow[t]{2}{*}{ Interface } & \multirow[t]{2}{*}{37} & Number & 37 \\
\hline & & Description & 22 \\
\hline \multirow[t]{3}{*}{ ItemLink } & \multirow[t]{3}{*}{37} & Number & 37 \\
\hline & & Is Constrained & false: 37 \\
\hline & & Abbreviation & 37 \\
\hline VerificationRequirement & 28 & & \\
\hline \multirow[t]{4}{*}{ Component } & \multirow[t]{4}{*}{24} & Description & 24 \\
\hline & & \multirow[t]{2}{*}{ Component Type } & System: 1 \\
\hline & & & System Segment: 18 \\
\hline & & Number & 24 \\
\hline Organization & 20 & Abbreviation & 5 \\
\hline \multirow[t]{2}{*}{ Category } & \multirow[t]{2}{*}{16} & Number & 4 \\
\hline & & Description & 8 \\
\hline VerificationMethod & 5 & & \\
\hline
\end{tabular}


HNF-SD-WM-TP-431 Rev. 3

\section{DATABASE PROFILE}

of

Facility: DOE

V41-TWRS-Rev1-Pending-093096+crs , im

11:00:59 am

Prepared By:

TWRS Systems Engineering 
TABLE 1 DOE Relationships

\begin{tabular}{|c|c|c|c|}
\hline ELEMENT TYPE* & INSTANCES & RELATIONSHIP NAME & RELATIONSHIPS \\
\hline \multirow[t]{19}{*}{ SystemRequirement } & \multirow[t]{19}{*}{1660} & \multirow[t]{9}{*}{ traces to } & Component 487 \\
\hline & & & CriticalIssue 5 \\
\hline & & & Decision 64 \\
\hline & & & Interface 28 \\
\hline & & & ItemLink 34 \\
\hline & & & RequiredAnalysis 1 \\
\hline & & & Source 4 \\
\hline & & & TimeFunction 5107 \\
\hline & & & TimeItem 2265 \\
\hline & & primary is & Organization 139 \\
\hline & & documented by & Source 1358 \\
\hline & & annotated by & Comment 151 \\
\hline & & invokes & Source 10 \\
\hline & & categorized by & Category 2221 \\
\hline & & incorporated by & SystemRequirement 1070 \\
\hline & & incorporates & SystemRequirement 1070 \\
\hline & & verified by & VerificationRequirement 27 \\
\hline & & traced from & CriticalIssue 359 \\
\hline & & & Decision 98 \\
\hline Timeltem & 881 & output from & TimeFunction 921 \\
\hline & & documented by & Source 1 \\
\hline & & traced from & CriticalIssue 179 \\
\hline
\end{tabular}

* Element Types with no instances are not listed. Element types are sorted by the number of instances. 
TABLE 1 DOE Relationships

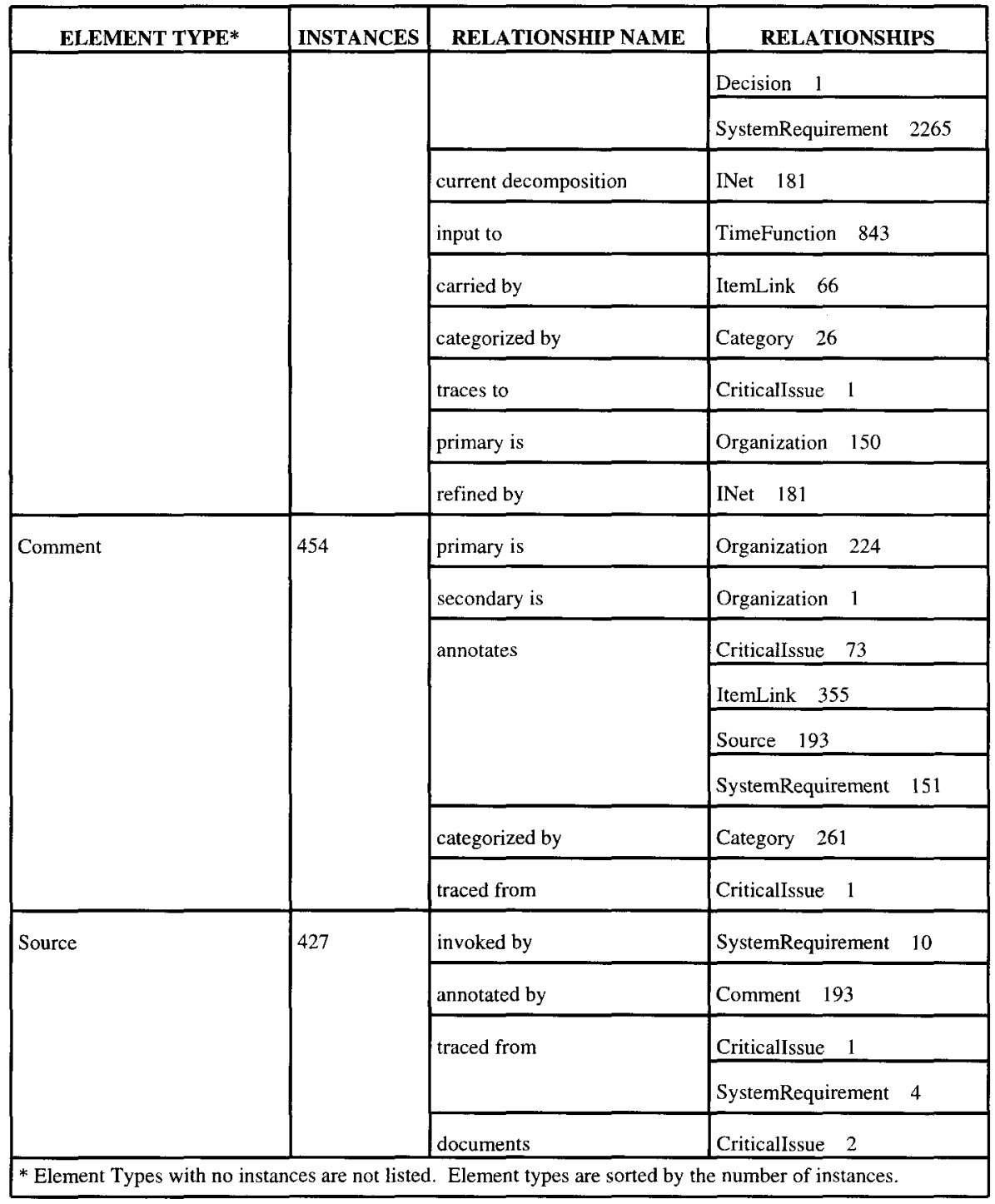


TABLE 1 DOE Relationships

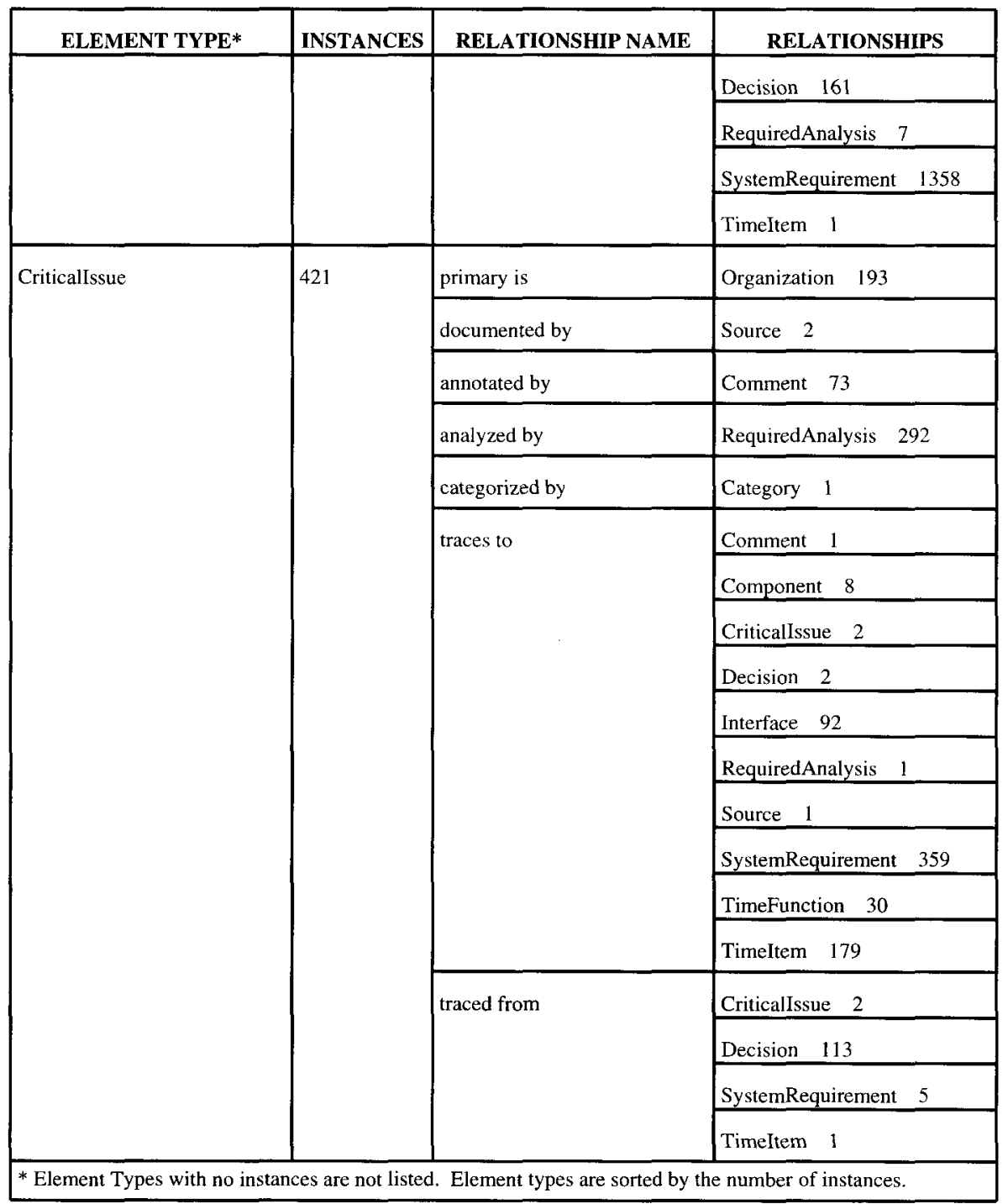


TABLE 1 DOE Relationships

\begin{tabular}{|c|c|c|c|}
\hline ELEMENT TYPE* & INSTANCES & RELATIONSHIP NAME & RELATIONSHIPS \\
\hline & & \multirow[t]{2}{*}{ raised by } & Component 6 \\
\hline & & & TimeFunction 6 \\
\hline \multirow[t]{8}{*}{ RequiredAnalysis } & \multirow[t]{8}{*}{364} & documented by & Source 7 \\
\hline & & primary is & Organization 186 \\
\hline & & secondary is & Organization 4 \\
\hline & & \multirow[t]{2}{*}{ analyzes } & CriticalIssue 292 \\
\hline & & & Decision 55 \\
\hline & & \multirow[t]{3}{*}{ traced from } & CriticalIssue 1 \\
\hline & & & Decision 1 \\
\hline & & & SystemRequirement 1 \\
\hline \multirow[t]{10}{*}{ TimeFunction } & \multirow[t]{10}{*}{326} & inputs & TimeItem 843 \\
\hline & & outputs & TimeItem 921 \\
\hline & & primary is & Organization 41 \\
\hline & & current decomposition & FNet 77 \\
\hline & & \multirow[t]{2}{*}{ performed by } & Component 18 \\
\hline & & & System 1 \\
\hline & & decomposed by & FNet 78 \\
\hline & & \multirow[t]{2}{*}{ traced from } & CriticalIssue $\quad 30$ \\
\hline & & & SystemRequirement 5107 \\
\hline & & raises & CriticalIssue 6 \\
\hline \multirow[t]{2}{*}{ Decision } & \multirow[t]{2}{*}{248} & categorized by & Category 4 \\
\hline & & traces to & Component 45 \\
\hline
\end{tabular}

* Element Types with no instances are not listed. Element types are sorted by the number of instances. 
TABLE 1 DOE Relationships

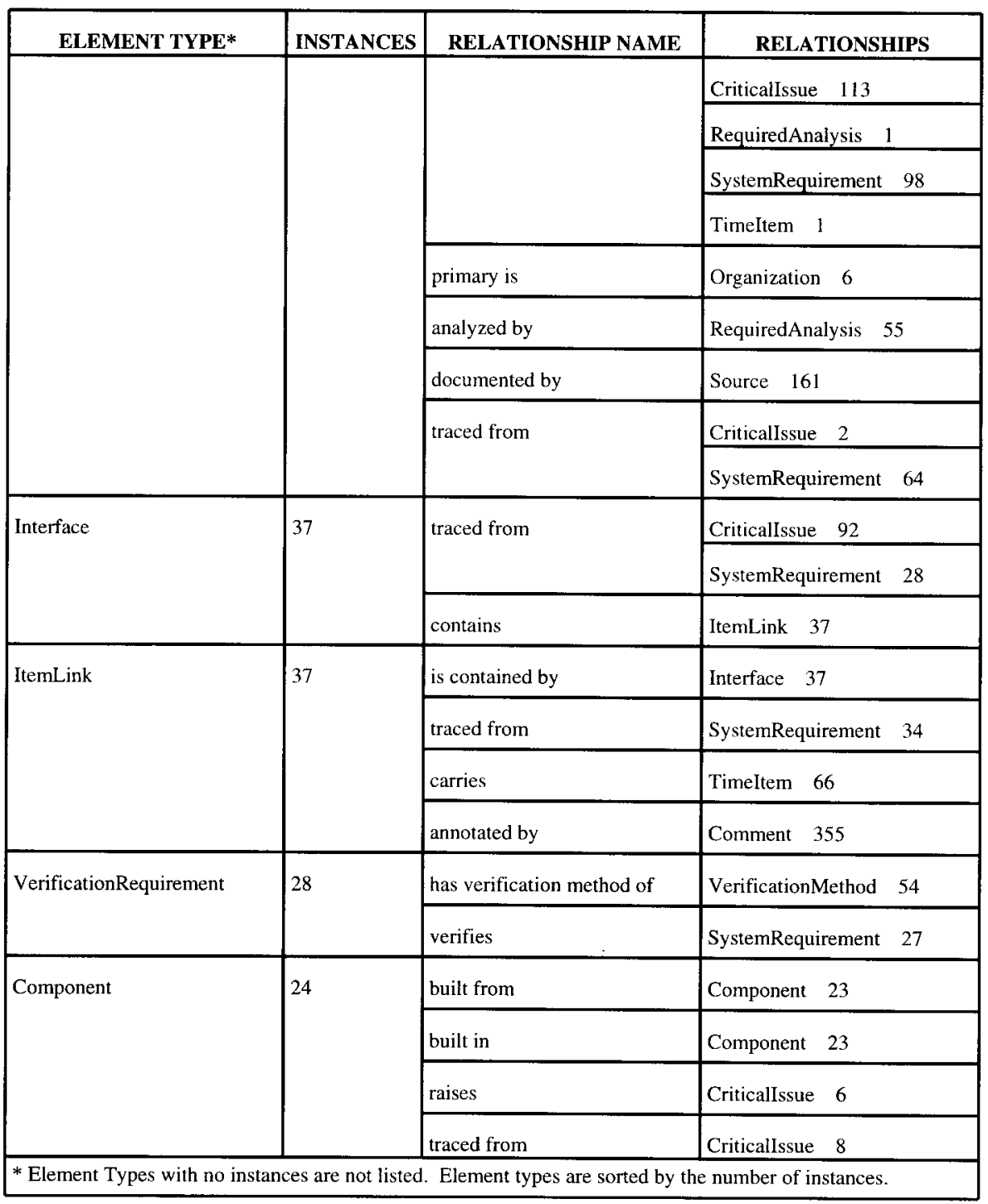


HNF-SD-WM-TP-431 Rev. 3

TABLE 1 DOE Relationships

\begin{tabular}{|c|c|c|c|}
\hline \multirow[t]{4}{*}{ ELEMENT TYPE* } & INSTANCES & RELATIONSHIP NAME & RELATIONSHIPS \\
\hline & & & Decision 45 \\
\hline & & & SystemRequirement 487 \\
\hline & & performs & TimeFunction 18 \\
\hline \multirow[t]{9}{*}{ Organization } & \multirow[t]{9}{*}{20} & \multirow[t]{7}{*}{ primary for } & Comment 224 \\
\hline & & & CriticalIssue 193 \\
\hline & & & Decision 6 \\
\hline & & & RequiredAnalysis 186 \\
\hline & & & SystemRequirement 139 \\
\hline & & & TimeFunction 41 \\
\hline & & & TimeItem 150 \\
\hline & & \multirow[t]{2}{*}{ secondary for } & Comment 1 \\
\hline & & & RequiredAnalysis 4 \\
\hline \multirow[t]{5}{*}{ Category } & \multirow[t]{5}{*}{16} & \multirow[t]{5}{*}{ categorizes } & Comment 261 \\
\hline & & & CriticalIssue 1 \\
\hline & & & Decision 4 \\
\hline & & & SystemRequirement 2221 \\
\hline & & & TimeItem 26 \\
\hline VerificationMethod & 5 & verification method for & VerificationRequirement 54 \\
\hline
\end{tabular}


HNF-SD-WM-TP-431 Rev. 3

TABLE 2 DOE Attributes

\begin{tabular}{|c|c|c|c|}
\hline ELEMENT TYPE* & INSTANCES & ATTRIBUTE NAME & ATTRIBUTES \\
\hline \multirow[t]{5}{*}{ SystemRequirement } & \multirow[t]{5}{*}{1660} & Number & 1262 \\
\hline & & Line Number & 1 \\
\hline & & Paragraph Title & 64 \\
\hline & & Status & Pending: 1 \\
\hline & & Description & 1585 \\
\hline \multirow[t]{5}{*}{ TimeItem } & \multirow[t]{5}{*}{881} & Number & 42 \\
\hline & & Message Priority & 881 \\
\hline & & Description & 865 \\
\hline & & Size & 881 \\
\hline & & IDEF0 Type & input: 881 \\
\hline \multirow[t]{2}{*}{ Comment } & \multirow[t]{2}{*}{454} & Description & 454 \\
\hline & & Number & 98 \\
\hline \multirow[t]{8}{*}{ Source } & \multirow[t]{8}{*}{427} & Description & 327 \\
\hline & & Abbreviation & 1 \\
\hline & & Number & 40 \\
\hline & & \multirow[t]{5}{*}{ Source Type } & $\begin{array}{l}\text { Originating Requirements: } \\
218 \\
\end{array}$ \\
\hline & & & Meeting Minutes: 1 \\
\hline & & & Trade-off Study Report: 4 \\
\hline & & & Project Memo: 6 \\
\hline & & & Standard: 3 \\
\hline \multirow[t]{4}{*}{ CriticalIssue } & \multirow[t]{4}{*}{421} & \multirow[t]{2}{*}{ Issue Type } & Issue: 418 \\
\hline & & & Required Analysis: 3 \\
\hline & & Due Date & 148 \\
\hline & & Priority & A (Very High): 13 \\
\hline
\end{tabular}


HNF-SD-WM-TP-431 Rev. 3

TABLE 2 DOE Attributes

\begin{tabular}{|c|c|c|c|}
\hline ELEMENT TYPE* & INSTANCES & ATTRIBUTE NAME & ATTRIBUTES \\
\hline & & Actual Date & 36 \\
\hline & & Description & 418 \\
\hline & & Number & 165 \\
\hline \multirow[t]{2}{*}{ RequiredAnalysis } & \multirow[t]{2}{*}{364} & Description & 357 \\
\hline & & Number & 174 \\
\hline \multirow[t]{4}{*}{ TimeFunction } & \multirow[t]{4}{*}{326} & Description & 316 \\
\hline & & Number & 324 \\
\hline & & Debugging Mode & none: 326 \\
\hline & & Execution Level & follow decomposition: 326 \\
\hline \multirow[t]{8}{*}{ Decision } & \multirow[t]{8}{*}{248} & Alternatives & 57 \\
\hline & & Problem & 2 \\
\hline & & Choice & 94 \\
\hline & & \multirow[t]{3}{*}{ Status } & Open: 4 \\
\hline & & & Enabling Assumption: 38 \\
\hline & & & Resolved: 103 \\
\hline & & Description & 139 \\
\hline & & Number & 127 \\
\hline \multirow[t]{2}{*}{ Interface } & \multirow[t]{2}{*}{37} & Description & 22 \\
\hline & & Number & 37 \\
\hline \multirow[t]{3}{*}{ ItemLink } & \multirow[t]{3}{*}{37} & Is Constrained & false: 37 \\
\hline & & Number & 37 \\
\hline & & Abbreviation & 37 \\
\hline VerificationRequirement & 28 & & \\
\hline Component & 24 & Component Type & System: 1 \\
\hline
\end{tabular}


HNF-SD-WM-TP-431 Rev, 3

TABLE 2 DOE Attributes

\begin{tabular}{|l|l|l|l|}
\hline \multirow{2}{*}{ ELEMENT TYPE* } & INSTANCES & ATTRIBUTE NAME & \multicolumn{1}{|c|}{ ATTRIBUTES } \\
\hline \multirow{2}{*}{} & & & System Segment: 18 \\
\cline { 3 - 4 } & & Description & 24 \\
\cline { 3 - 4 } & & Number & 24 \\
\hline \multirow{2}{*}{ Organization } & 20 & Abbreviation & 5 \\
\hline \multirow{2}{*}{ Category } & 16 & Description & 8 \\
\cline { 2 - 4 } & & Number & 4 \\
\hline \multirow{2}{*}{ VerificationMethod } & 5 & & \\
\hline * Element Types with no instances are not listed. Element types are sorted by the number of instances.
\end{tabular}


HNF-SD-WM-TP-431 Rev. 3

\section{DATABASE PROFILE}

$$
\text { of }
$$

\section{Facility: DOE}

V411-TWRS-Rev1-Pending-093096+crs im

\section{1:59:14 pm}

\section{Prepared By:}

\section{TWRS Systems Engineering}


TABLE 1 DOE Relationships

\begin{tabular}{|c|c|c|c|}
\hline ELEMENT TYPE* & INSTANCES & RELATIONSHIP NAME & RELATIONSHIPS \\
\hline \multirow[t]{19}{*}{ SystemRequirement } & \multirow[t]{19}{*}{1660} & documented by & Source 1358 \\
\hline & & verified by & VerificationRequirement 27 \\
\hline & & annotated by & Comment 151 \\
\hline & & primary is & Organization 139 \\
\hline & & \multirow[t]{2}{*}{ traced from } & \begin{tabular}{|l} 
CriticalIssue $\quad 359$ \\
\end{tabular} \\
\hline & & & Decision 98 \\
\hline & & \multirow[t]{9}{*}{ traces to } & Component 487 \\
\hline & & & CriticalIssue 5 \\
\hline & & & Decision 64 \\
\hline & & & Interface 28 \\
\hline & & & ItemLink 34 \\
\hline & & & RequiredAnalysis 1 \\
\hline & & & Source 4 \\
\hline & & & TimeFunction 5107 \\
\hline & & & TimeItem 2299 \\
\hline & & invokes & Source 10 \\
\hline & & categorized by & Category 2221 \\
\hline & & incorporated by & SystemRequirement 1070 \\
\hline & & incorporates & SystemRequirement 1070 \\
\hline \multirow[t]{12}{*}{ TimeItem } & \multirow[t]{12}{*}{898} & refined by & INet 182 \\
\hline & & carried by & ItemLink 68 \\
\hline & & primary is & Organization 150 \\
\hline & & current decomposition & INet 182 \\
\hline & & traces to & Criticallssue 1 \\
\hline & & documented by & Source 1 \\
\hline & & output from & TimeFunction 939 \\
\hline & & traced from & CriticalIssue 179 \\
\hline & & & Decision 1 \\
\hline & & & SystemRequirement 2299 \\
\hline & & input to & TimeFunction 851 \\
\hline & & categorized by & Category 26 \\
\hline Comment & 454 & annotates & Criticallssue 73 \\
\hline
\end{tabular}


HNF-SD-WM-TP-431 Rev. 3

TABLE 1 DOE Relationships

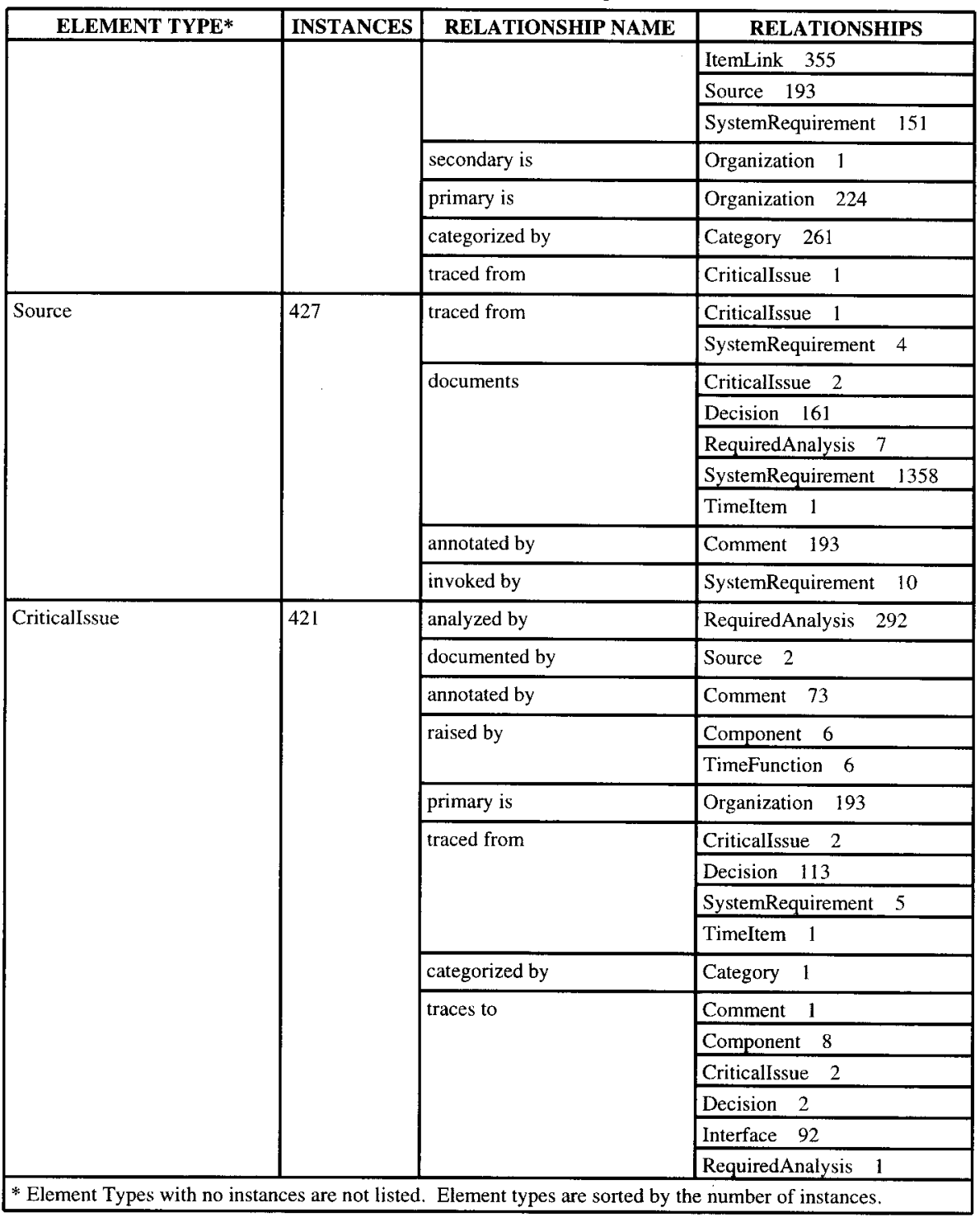


HNF-SD-WM-TP-431 Rev. 3

TABLE 1 DOE Relationships

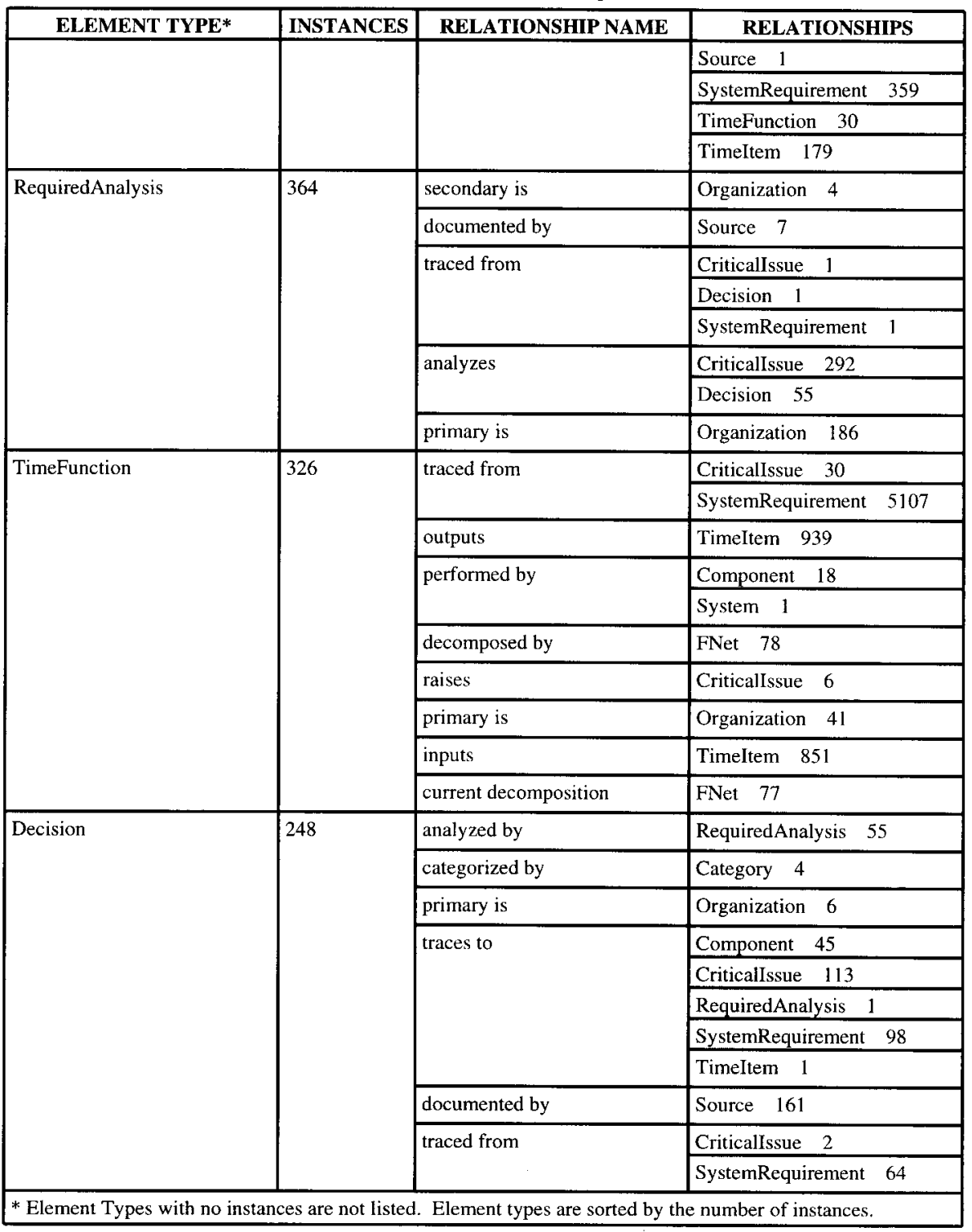


TABLE 1 DOE Relationships

\begin{tabular}{|c|c|c|c|}
\hline ELEMENT TYPE* & INSTANCES & RELATIONSHIP NAME & RELATIONSHIPS \\
\hline \multirow[t]{3}{*}{ Interface } & \multirow[t]{3}{*}{37} & contains & ItemLink 37 \\
\hline & & \multirow[t]{2}{*}{ traced from } & \begin{tabular}{|l} 
CriticalIssue 92 \\
\end{tabular} \\
\hline & & & SystemRequirement 28 \\
\hline \multirow[t]{4}{*}{ ItemLink } & \multirow[t]{4}{*}{37} & carries & TimeItem 68 \\
\hline & & is contained by & Interface 37 \\
\hline & & annotated by & Comment 355 \\
\hline & & traced from & SystemRequirement 34 \\
\hline \multirow[t]{2}{*}{ VerificationRequirement } & \multirow[t]{2}{*}{28} & has verification method of & VerificationMethod 54 \\
\hline & & verifies & SystemRequirement 27 \\
\hline \multirow[t]{7}{*}{ Component } & \multirow[t]{7}{*}{24} & performs & TimeFunction 18 \\
\hline & & \multirow[t]{3}{*}{ traced from } & CriticalIssue 8 \\
\hline & & & \begin{tabular}{|l|} 
Decision 45 \\
\end{tabular} \\
\hline & & & SystemRequirement 487 \\
\hline & & built from & Component 23 \\
\hline & & built in & Component 23 \\
\hline & & raises & CriticalIssue 6 \\
\hline \multirow[t]{9}{*}{ Organization } & \multirow[t]{9}{*}{20} & \multirow[t]{7}{*}{ primary for } & Comment 224 \\
\hline & & & \begin{tabular}{|ll} 
CriticalIssue 193 \\
\end{tabular} \\
\hline & & & Decision 6 \\
\hline & & & RequiredAnalysis 186 \\
\hline & & & SystemRequirement 139 \\
\hline & & & TimeFunction 41 \\
\hline & & & TimeItem 150 \\
\hline & & \multirow[t]{2}{*}{ secondary for } & Comment 1 \\
\hline & & & RequiredAnalysis 4 \\
\hline \multirow[t]{5}{*}{ Category } & \multirow[t]{5}{*}{16} & categorizes & Comment 261 \\
\hline & & & Criticallssue 1 \\
\hline & & & Decision 4 \\
\hline & & & SystemRequirement 2221 \\
\hline & & & TimeItem 26 \\
\hline VerificationMethod & 5 & verification method for & VerificationRequirement 54 \\
\hline
\end{tabular}


HNF-SD-WM-TP-431 Rev . 3

TABLE 2 DOE Attributes

\begin{tabular}{|c|c|c|c|}
\hline ELEMENT TYPE* & INSTANCES & ATTRIBUTE NAME & ATTRIBUTES \\
\hline \multirow[t]{5}{*}{ SystemRequirement } & \multirow[t]{5}{*}{1660} & Paragraph Title & 64 \\
\hline & & Status & Pending: 1 \\
\hline & & Description & 1585 \\
\hline & & Number & 1262 \\
\hline & & Line Number & 1 \\
\hline \multirow[t]{5}{*}{ TimeItem } & \multirow[t]{5}{*}{898} & Description & 882 \\
\hline & & Message Priority & 898 \\
\hline & & Size & 898 \\
\hline & & Number & 44 \\
\hline & & IDEF0 Type & input: 898 \\
\hline \multirow[t]{2}{*}{ Comment } & \multirow[t]{2}{*}{454} & Number & 98 \\
\hline & & Description & 454 \\
\hline \multirow[t]{8}{*}{ Source } & \multirow[t]{8}{*}{427} & Abbreviation & 1 \\
\hline & & Number & 40 \\
\hline & & Description & 327 \\
\hline & & \multirow[t]{5}{*}{ Source Type } & $\begin{array}{l}\text { Originating Requirements: } \\
218\end{array}$ \\
\hline & & & Meeting Minutes: 1 \\
\hline & & & Trade-off Study Report: 4 \\
\hline & & & Project Memo: 6 \\
\hline & & & Standard: 3 \\
\hline \multirow[t]{7}{*}{ CriticalIssue } & \multirow[t]{7}{*}{421} & Priority & A (Very High): 13 \\
\hline & & Description & 418 \\
\hline & & Actual Date & 36 \\
\hline & & \multirow[t]{2}{*}{ Issue Type } & Issue: 418 \\
\hline & & & Required Analysis: 3 \\
\hline & & Due Date & 148 \\
\hline & & Number & 165 \\
\hline \multirow[t]{2}{*}{ RequiredAnalysis } & \multirow[t]{2}{*}{364} & Description & 357 \\
\hline & & Number & 174 \\
\hline \multirow[t]{4}{*}{ TimeFunction } & \multirow[t]{4}{*}{326} & Debugging Mode & none: 326 \\
\hline & & Description & 316 \\
\hline & & Number & 324 \\
\hline & & Execution Level & follow decomposition: 326 \\
\hline \multirow[t]{3}{*}{ Decision } & \multirow[t]{3}{*}{248} & Problem & 2 \\
\hline & & Description & 139 \\
\hline & & Choice & 94 \\
\hline
\end{tabular}


HNF-SD-WM-TP-431 Rev. 3

TABLE 2 DOE Attributes

\begin{tabular}{|c|c|c|c|}
\hline ELEMENT TYPE* & INSTANCES & ATTRIBUTE NAME & ATTRIBUTES \\
\hline & & \multirow[t]{3}{*}{ Status } & Open: 4 \\
\hline & & & Enabling Assumption: 38 \\
\hline & & & Resolved: 103 \\
\hline & & Altematives & 57 \\
\hline & & Number & 127 \\
\hline \multirow[t]{2}{*}{ Interface } & \multirow[t]{2}{*}{37} & Number & 37 \\
\hline & & Description & 22 \\
\hline \multirow[t]{3}{*}{ ItemLink } & \multirow[t]{3}{*}{37} & Number & 37 \\
\hline & & Is Constrained & false: 37 \\
\hline & & Abbreviation & 37 \\
\hline VerificationRequirement & 28 & & \\
\hline \multirow[t]{4}{*}{ Component } & \multirow[t]{4}{*}{24} & Description & 24 \\
\hline & & \multirow[t]{2}{*}{ Component Type } & System: 1 \\
\hline & & & System Segment: 18 \\
\hline & & Number & 24 \\
\hline Organization & 20 & Abbreviation & 5 \\
\hline \multirow[t]{2}{*}{ Category } & \multirow[t]{2}{*}{16} & Number & 4 \\
\hline & & Description & 8 \\
\hline VerificationMethod & 5 & & \\
\hline
\end{tabular}


HNF-SD-WM-TP-431 Rev. 3

APPENDIX C

\section{Database Content Differences}

The UNIX "diff" utility found no differences between the two sets of data.

C-1 